\title{
Sønderjyder for tysk krigsret i 1940
}

\author{
af Frode Sørensen
}

Begik Viggo Lausten selvmord, efter at han var blevet arresteret af tyskerne i 1940? Nej. Det var tysk »hjælp« til selvmord. Eller sagt direkte: Han blev myrdet. Døde Peter A. Dons af hjertestop som følge af en overdosis af sin egen medicin? Nej, han blev også myrdet. Frode Sørensen har haft adgang til hidtil lukkede arkiver og forsket i historien om den forste krigsretssag, som blev gennemført i ugerne efter den tyske besættelse af Danmark den 9. april 1940. Det er bemærkelsesværdige oplysninger, han lægger frem. 13 sønderjyder blev anholdt og sigtet for spionagevirksomhed mod Tyskland. To af dem døde. Frode Sørensen stiller spørgsmålet: Hvorfor ville de danske myndigheder ikke have sagen fuldt opklaret?

Dette er ikke alene historien om den første krigsretssag i ugerne efter den tyske besættelse. Det er også historien om de hændelser, der foregik i 1930'erne, og som blev udslaggivende for anholdelsen af 13 sønderjyder, hvoraf de to døde under mystiske omstændigheder i forbindelse med afhøringer i Kastellet i København. Det er også historien om den danske regerings manglende lyst til at undersøge sagen såvel i krigens første fase som efter krigen og senest i 1971, hvor der var en forespørgsel i Folketinget fra det konservative folketingsmedlem Johannes Burgdorf, Brændstrup, til partifællen, daværende justitsminister Knud Thestrup.

Den tyske besættelsesmagts første krigsretssag i 1940 var rettet mod 13 personer fra Sønderjylland, mistænkt for spionage mod NaziTyskland til fordel for England. De blev anholdt og arresteret fra 12. til 28. april 1940. Deres navne var: Jens Dons, Alfred Petersen, Viggo Lausten, Peter Andersen Dons, Hans Peter Lythje, Nicolaus Wind, Carl Johan Bech, Simon Sørensen Madsen, Emil Fries, Lorentz H. Jepsen, Carl Engberg, Hans Thomas Lützen og Georg Sager.

De to, som tysk militær 12. april, uden information til danske myndigheder, kidnappede på deres bopæl, blev straks ført til Flensborg og fængslet dér. Af de 11, der blev anholdt af dansk politi 20., 26. og 28. april, blev de ti indsat i arresten i Aabenraa og den sidste i Haderslev. De 11 fik at vide, at de var sigtet efter paragraf 105 i Lov nr. 26 
i Borgerlig Straffelov. Loven var vedtaget 11. april 1930 og på grund af Tysklands aggressive fremfærd ændret 11. juli 1939: Paragraffen var efter den seneste ændring formuleret således:

"Den, som foretager noget, hvorved en fremmed Stats Efterretningsvæsen sættes i Stand til eller hjælpes til umiddelbart eller middelbart at virke inden for den danske Stats Omraade, straffes med Fængsel indtil 6 Aar eller under formildende Omstændigheder med Hæfte«.

Den væsentligste ændring i 1939 var, at »fængsel $i$ indtil 2 år « nu var "fængsel i indtil 6 år«. Forhøjelsen af strafferammen var ikke genstand for den store debat. I bemærkningerne blev det noteret, at strafferammerne for spionage havde været "overordentlig milde", og at der derfor var god grund til at skærpe dem. Justitsminister K.K. Steincke formulerede det således:

"Ændringen af disse paragraffer sætter jo ind på tre punkter, dels ved at sondre mellem den fare, der er for fjendtlige forholdsregler og for fremmed magts indblanding, dels ved at straffe ikke alene spionage for fremmed militærs efterretningsvæsen, men også for fremmed stats efterretningsvæsen, og dels endelig ved en kraftig forhøjelse af strafferammerne for disse forbrydelser mod statens sikkerhed « ${ }^{1}$

Der var i Folketinget og Landstinget i 1939 bred enighed om, at den faretruende situation i Europa anført af det aggressive Tyskland af hensyn til Danmarks sikkerhed nødvendiggjorde en kraftig skærpelse af strafferammen for spionage.

\section{Situationen før 9. april 1940}

I Berlin underskrev den tyske udenrigsminister von Ribbentrop og den danske gesandt, kammerherre Herluf Zahle den 31. maj 1939 den dansk-tyske ikke-angrebspagt. Aftalen blev ratificeret af udenrigsminister P. Munch den 24. juni og offentliggjort 30. juni 1939. Den 1. maj 1939 havde rigspolitichef Eigil Thune Jacobsen, med udgangspunkt i Lov nr. 43 af 15. marts 1939, etableret Sikkerhedspolitiet (SIPO). Afdelingen fik direkte reference til rigspolitichefen, og første chef blev politiinspektør Emil G. Strøbech. Sikkerhedspolitiets aktiviteter i efteråret $1939 \mathrm{og}$ begyndelsen af 1940 skulle få stor betydning for den første tyske krigsretssag i Danmark. 
Strøbech var chef for SIPO, indtil han i marts 1940 på grund af alvorlige uoverensstemmelser blev fjernet fra jobbet. ${ }^{2}$ Det svækkede SIPO's position, som i forvejen havde mistet noget af sin politiske opbakning efter at Svend Unmack Larsen den 15. september 1939 havde afløst K. K. Steincke som justitsminister.

Fra starten af SIPO's etablering var der tætte kontakter til det tyske Gestapo. Forfatteren H. E. Sørensen, Skærbæk, som i 1971 indgående undersøgte den spionagesigtede redaktør Viggo Laustens død, påviste dengang, at der i november 1939 var kontakt mellem SIPO og Gestapo i Kiel, og på opfordring af Thune Jacobsen var Strøbech i sommeren 1939 otte dage i Berlin for at se på Gestapos organisation og måske få "staldfiduser. ${ }^{3}$

At der var kontakt mellem Gestapo i Kiel og SIPO, dokumenteres af en skrivelse dateret 4. november 1939 fra Oberkommando der Wehrmacht til Abwehrstelle Kiel, Geheime Statspolizei ved SS-Obersturmführer Müller, som omtalte det bestående samarbejde med Herrn Ströbeck. I samme skrivelse blev en dansk indsats for at skaffe bevismateriale mod en tysk emigrant omtalt. I parentes er anført "Chef der Dänischen Sicherheitspolizei Ströbeck «. ${ }^{4}$

Rigspolitichef Thune Jacobsen havde $\mathrm{i}$ forbindelse med sin deltagelse i internationalt politisamarbejde flere kontakter til højtrangerende personer i Gestapo i Berlin. ${ }^{5}$ I maj 1939 deltog han i en konference i Leipzig, og på hjemvejen skulle han have gjort stop i Berlin for at mødes med SS-Reichsführer Heinrich Himmler efter dennes invitation. Mødet blev dog ikke til noget, da Himmler meldte afbud på grund af forkølelse. ${ }^{6}$ I pinsen 1939 fik Thune Jacobsen besøg af to tyske kolleger fra den Internationale Kriminal-Politikommission i Wien, general Nebe og ministerialrat Zindel, begge fra Berlin.

Senest fra begyndelsen af 1939 var der altså tætte dansk-tyske kontakter, og der er ingen grund til at betvivle, at såvel rigspolitichefen som lederen af sikkerhedspolitiet $\mathrm{i} 1939$ havde tætte relationer til højtplacerede personer i Gestapo. Under en kommissionsafhøring i december 1946 blev Thune Jacobsen spurgt, om der var kontakter mellem SIPO og tyske politikredse. Han svarede: "Ikke det jeg ved af. Jeg tror ganske bestemt, at jeg kan sige nej her.«

Det virker besynderligt, at kommissionen ikke gik noget hårdere til Thune Jacobsen. Straks efter besættelsen den 9. april 1940 blev en stor del af SIPO's arkiver på Politigården brændt, og selvom Strøbech var fratrådt, havde han lovet Thune Jacobsen at være behjælpelig ved 
en gennemgang og afbrænding af følsomme akter. Under denne afbrænding opstod der en heftig diskussion mellem Strøbech og Thune Jacobsen, idet Strøbech mente, at mest muligt skulle brændes, især materiale om spionage til fordel for Frankrig og England mod Tyskland. Strøbech mente, at danske borgere kunne komme i klemme, såfremt tyskerne fik fingre i materialet.

Thune Jacobsen modtog den 9. eller 10. april en opringning fra Det tyske Gesandtskab på Dagmarhus. En ophidset presseattaché, Friedrich Frielitz, fortalte, »at han havde fået meddelelse om, at der blev brændt dokumenter i Politigårdens fyr, og Frielitz ville gøre Thune Jacobsen personligt ansvarlig for brændte dokumenter. ${ }^{7}$

Thune Jacobsen svarede, at han intet kendte til sagen, men at han ville undersøge den. Thune Jacobsen var selvfølgelig fuldt oplyst, da såvel justitsministeren som udenrigsministeren havde givet tilladelse til at tilintetgøre belastende materiale, men ikke alt. Ministerierne var nemlig bange for tyskernes reaktion, såfremt intet var tilbage.

Det var det, diskussionen mellem Strøbech og Thune Jacobsen drejede sig om. Sidstnæunte mente, at Strøbech havde brændt for meget. Men Strøbech henholdt sig til en meddelelse fra Rigsregistraturen om, "at det som efter personalets skøn kunne skade danske borgere var eller ville blive brændt $\propto .{ }^{8}$

Thune Jacobsens forsøg på at bremse Strøbech, slog fejl. Væsentlige dele af SIPO's arkiv blev tilintetgjort.

Dog ikke materialet om overvågning af den tidligere forsikringsagent Jens Dons, Kolding, tidl. Mjolden, og tidligere mejerimontør, måleraflæser Alfred Petersen, Strandelhjørn.

\section{Situationen i Sønderjylland før 9. april 1940}

I begyndelsen af oktober 1939 blev SIPO kontaktet af folketingsmedlem Jørgen Gram, Gabøl, der oplyste, at han havde fået en henvendelse fra den sønderjyske gårdejer Jørgen Juhl, der havde oplysninger om spionage mod Tyskland til fordel for England (Jørgen Juhl er et opdigtet navn. Forfatteren er bekendt med det virkelige navn).

De mistænkte var tidligere mejerimontør, måleraflæser Alfred Petersen, Strandelhjørn, og tidligere forsikringsagent Jens Dons, Kolding.

Efter aftale med Jørgen Gram afhørte SIPO Jørgen Juhl den 11. oktober 1939. Han fortalte, at Dons var leder af en slags efterretningscentral, og at Alfred Petersen i nogle år havde arbejdet for ham. Juhl 


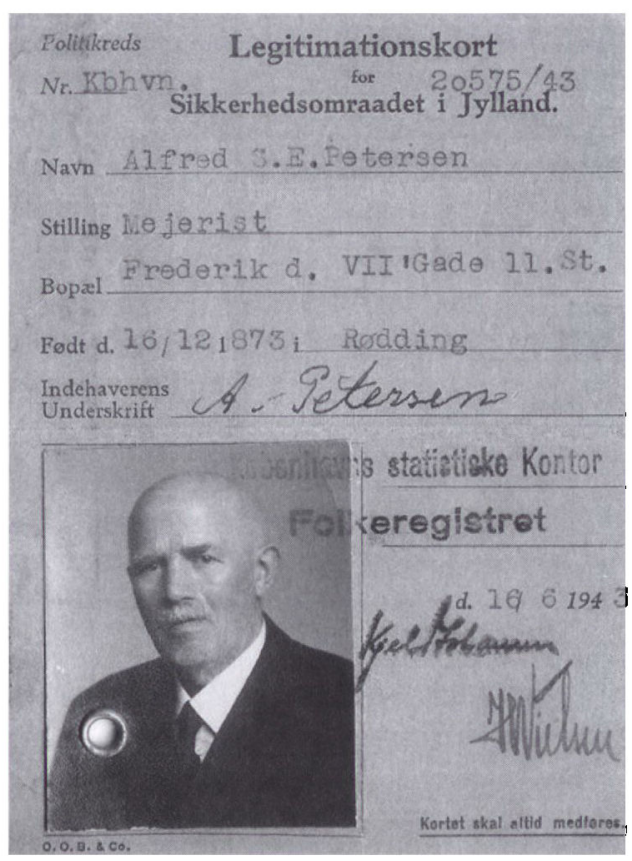

Alfred S.E. Petersen blev arresteret den 12. april 1940, sigtet for spionage til fordel for England. Petersen havde $i$ slutningen af 1930 'erne leveret oplysninger om tyske militære anlæg til Secret Service. Den 31. august 1940 blev han idomt knap fem års fxngsel ved Københavns Byret. Alfred S.E. Sørensen blev benådet den 5. juni 1943. Legitimationskortet er udstedt fä dage senere. I privateje.

oplyste, at Petersen havde levet en omtumlet tilværelse med forskellige jobs i både Danmark, Tyskland og Rusland. ${ }^{9}$ Det var Juhls opfattelse, at Petersen ofte rejste til Kiel og Cuxhaven for at observere militære installationer. I begyndelsen havde han afleveret sine beretninger til Dons, men den seneste tid havde han arbejdet selvstændigt. Fra et postkort, som Juhl selv havde set, kunne han oplyse, at Petersens kontaktperson i Kobenhavn hed Byron, og at Alfred Petersen skulle til København for at få nye opgaver. ${ }^{10}$

I øvrigt var det Juhls opfattelse, at Petersen i starten ikke var klar over, at hans forehavende var ulovligt. Kort før Tysklands invasion af Polen 1. september 1939 var Petersen i København. Byron ønskede, at han skulle rejse til Kiel eller Cuxhaven. Tilsyneladende turde Petersen ikke rejse på grund af den tilspidsede situation, hvorfor han udfærdigede en fiktiv rapport, som han sendte til Byron. ${ }^{11}$

På baggrund af Juhls oplysninger tog SIPO 12. oktober 1939 kontakt til politiet i Kolding med henblik på at få observeret Dons' og Petersens færden. Inden kontakten til politiet i Kolding havde SIPO erfaret, at Dons og Petersen havde været i København 18. august. 
De havde overnattet på Hotel Ansgar i Colbjørnsensgade 29. Efter at politimesteren i Kolding var blevet orienteret, blev en dommer kontaktet, og politiet fik tilladelse til telefonaflytning, tilbageholdelse af post og telegrammer samt ransagning hos Dons, såfremt det var nødvendigt. Den 13. oktober gav Nr. Rangstrup og Hviding Herreds Ret i Toftlund samme tilladelse for så vidt angik Alfred Petersen.

Politiet fandt hurtigt ud af, at Dons og Petersen skulle mødes i Kolding 19. oktober, så fra Petersens ankomst til Kolding Banegård og ved deres besøg på to af byens restauranter blev de skygget af politiet.

Observationerne af Dons fortsatte året ud. Man kontrollerede alle hans bevægelser, ligesom hans telefon blev aflyttet. Men politiet måtte konstatere, at Dons var meget forsigtig. Noget må politiet dog have fundet ud af, for den 4 . november konkluderede politiet i et tillæg til en rapport af 31. oktober, "at der er fremkommet oplysninger, som lader formode, at Peter A. Dons (broder til hovedmistænkte) er impliceret. « ${ }^{12}$

Sidste gang, Juhl optrådte som »meddeler« til SIPO, var den 11. november 1939, hvor han oplyste til politiet i Toftlund, at Petersen havde fortalt ham om sit sidste møde i København. Han havde givet en englænder oplysninger, der efter Juhls opfattelse var spionage mod Tyskland til fordel for England. Petersens møde foregik på Cafe Royal nær Hovedbanegården, og tjeneren forklarede senere til SIPO, at englænderen, der tilsyneladende var et kendt ansigt på cafeen, forstod og talte noget dansk. Petersen havde også fortalt Juhl, at han på sin sidste tur til Kiel havde fået kontakt til en tysk dame, »Hertha«, der havde skaffet ham oplysninger om Kiels havn.

SIPO tog også kontakt til en del folk på Skærbæk-kanten, hvor Dons havde boet, og det var ikke noget positivt skudsmål, han fik der. Han blev betragtet som "en lusket og upålidelig person, som er $\mathbf{i}$ stand til at gøre alt for penge«. En anden udtrykte det således: "Dons' hovedinteresse er at tjene penge - hensigten helliger midlet«. Af de samtaler, som SIPO havde med Skærbæk-folk, kom det frem, at mange på egnen mistænkte ham for spionage. Man var bare i tvivl om, hvorvidt det var for Tyskland eller England. ${ }^{13}$

\section{Fra 9. april til 30. april 1940}

På et møde 12. april 1940 hos udenrigsminister P. Munch med deltagelse af direktør i Udenrigsministeriet O.C. Mohr, rigspolitichef E. Thune Jacobsen, Udenrigsministeriets chef for den politisk-juridiske afdeling, 
Nils Svenningsen, og fra tysk side af gesandt Renthe-Fink og lederen af Abwehrstelle Kopenhagen, Fregattenkapitän Howoldt, meddelte Renthe-Fink ved mødets start, "at alle sager ang. spionage, sabotage og Zersetzung (ødelæggelse) mod den tyske værnemagt efter folkeretten og den tyske militære straffelovgivning var undergivet den tyske krigsret, og værnemagten ønskede selv at gennemføre undersøgelser og afsige dom i disse sager ved egne organer, som man selv medbragte. « ${ }^{14}$

Udenrigsministeren og rigspolitichefen protesterede omgående. De ønskede et samarbejde mellem dansk politi og tysk militær. De politimæssige undersøgelser, anholdelser og fængslinger skulle foretages af danske politimyndigheder, ligesom anholdte skulle sidde i dansk fængsel. På mødet kom der en vis opblødning fra tysk side over for de danske ønsker, og efter yderligere forhandlinger fik Thune Jacobsen lovning på, at såvel undersøgelse som retspleje skulle foregå hos dansk politi. ${ }^{15}$ Et konkret resultat af mødet blev, at danske statsborgere, der umiddelbart efter besættelsen var blevet anholdt af tysk militær, ville blive løsladt eller overgivet til dansk politi.

Den 12. april havde de danske myndigheder ikke fuldt overblik over, hvor mange eller hvem der var blevet afhentet af tyskerne, og hvor de befandt sig. Tyskerne havde dog intet hastværk, og der skulle gå flere måneder, før aftalen var fuldbyrdet. Som en konsekvens af de tyske »indrømmelser « forlangte Renthe-Fink og Howoldt, at alle fællessager blev henlagt under én bestemt dansk embedsmand, og 15. april 1940 blev det aftalt, at statsadvokat Harald Petersen skulle være det officielle bindeled mellem de danske og de tyske myndigheder.

Den 17. april vendte tyskerne på en tallerken, og det tyske gesandtskab meddelte, at straffesager angående forbrydelser mod værnemagten hørte under tysk krigsret og skulle pådømmes efter tyske love. ${ }^{16}$

Statsadvokat Harald Petersen kom nu på arbejde. Fra 19. april til 27. april krævede Howoldt, at 15 personer blev anholdt. I et brev 19. april skrev Howoldt til Harald Petersen og refererede til en samtale samme dag angående fængslingen af Jens Dons: »Efter tilståelsen af den i Flensborg arresterede Jens Dons står følgende i betalt tjeneste hos Secret Service". Howoldt onskede også, at Harald Petersen skulle undersøge, om den tidligere ansatte ved det franske konsulat, Cramer, stadig befandt sig i København. ${ }^{17}$

Af de 15 var 11 sønderjyder, hvoraf to var tyske statsborgere (Lausten og Sager), to englændere, én københavner og en person med navnet Burmann, hvis identitet aldrig blev fuldt opklaret. 
De to englændere, der var ansat på Det britiske Paskontor, Bornholmsgade 3, frk. Lucy Bracken og Ernst Roscher, havde dog begge forladt landet med det såkaldte diplomattog fra Københavns Hovedbanegård den 13. april 1940.

Politiet i Sønderjylland blev pålagt at arrestere de 11. Harald Petersen nægtede dog at efterkomme kravet fra Howoldt om, at de arresterede straks skulle føres til København og overdrages til det tyske militær.

Den 22. april kom en ny tysk udmelding, da Renthe-Fink skrev til Udenrigsministeriets direktør O. C. Mohr, at »dansk politi skulle foretage arrestationer af danske statsborgere, og danske domstole skulle afsige fængslingskendelse over sådanne personer, som tyskerne onskede sat fast."

Mødevirksomheden mellem det danske udenrigs- og justitsministerium og den tyske værnemagt var genstand for stor opmærksomhed på den danske regerings daglige ministermøder. ${ }^{18}$ Allerede den 11. april besluttede ministermødet, at der skulle optages forhandlinger med tyskerne for at forhindre, at de uden dansk viden hentede folk til afhøring og arresterede dem.

Søndag den 28. april blev Harald Petersen kaldt til Hotel Cosmopolite på Kgs. Nytorv, hvor tysk militær havde indrettet sit hovedkontor. ${ }^{19}$ Han blev modtaget af Howoldt, som forlangte de i Sønderjylland arresterede overført til krigsretten i Kobenhavn. Da dette krav var i klar strid med den indgåede aftale, ville Harald Petersen ikke umiddelbart efterkomme det. Han drøftede også kravet med Oberkriegsgerichtsrat Jänz, der i utvetydige vendinger forklarede ham, at man ønskede fangerne udleveret, og han bad Petersen kontrasignere udleveringsskrivelser, affattet på tysk, til politimestrene i Aabenraa og Haderslev. Harald Petersen ville ikke skrive under, og Jänz måtte til sidst acceptere, at Petersen forst ville tale med justitsministeren.

Lynhurtigt blev der arrangeret et møde med deltagelse af justitsminister Unmack Larsen, udenrigsminister P. Munch, O. C. Mohr og ambassadør Zahle, der var hjemme fra Berlin. Nils Svenningsen, der var referent, skrev senere som kommentar til accepten af fangernes udlevering: "Man traf denne beslutning (så vidt jeg har forstået) under indtryk af, at tyskerne havde fremsat et ultimativt krav med trussel om selv at hente de pågældende fængslede, såfremt man ikke fra dansk side frivilligt udleverede dem.«

Man enedes om udlevering under protest. Sagen skulle straks tages op ad diplomatisk vej. 
På ministermødet den 29. april kl. 10 meddelte justitsministeren, at man under protest havde måttet imødekomme et krav fra den øverstkommanderende i Danmark, general Kaupisch, om at overføre nogle personer, der var sigtet $i$ en særlig spionsag. ${ }^{20}$ Fra tysk side blev det fremhævet, at der ikke herved var skabt nogen præcedens for fremtidige sagers behandling. O.C. Mohr tog 29. april om eftermiddagen sagen op over for Renthe-Fink, der undskyldte med, at det af hensyn til sagens hemmeligholdelse var nødvendigt, at undersøgelsen blev foretaget af de tyske myndigheder. Om aftenen lykkedes det Svenningsen at få telefonisk forbindelse med vicepolitipræsident Paul Kanstein i det tyske gesandtskab. Kanstein gjorde opmærksom på, at man havde mistanke om, at de anholdte også havde spioneret efter den 9. april 1940, og »såfremt denne mistanke ikke måtte bekræfte sig, ville de arresterede blive overgivet til de danske justitsmyndigheder under forelæggelse af bevismaterialet. Når det danske politi ikke skulle medvirke ved undersøgelsen, var det af hensyn til hemmeligholdelsen, " forklarede den tyske diplomat.

Svenningsen protesterede og tilkendegav, at denne fremgangsmåde stred imod den indgåede aftale, og at de arresterede ville være lige så isolerede $\mathrm{i}$ dansk fængsel som $\mathrm{i}$ tysk militær varetægt.

Kanstein og Svenningsen mødtes igen 30 . april, og de blev tilsyneladende enige om, at de fængslede kunne sidde i dansk fængsel i Kobenhavn. De danske myndigheder skulle garantere for, at de var isolerede under undersøgelsen. Forhøret skulle foretages af en tysk krigsretsdommer sammen med en dansk justitsembedsmand. Men kl. 18.40 samme dag meddelte Kanstein imidlertid, at tyskerne kunne gå med til følgende: "De arresterede anbringes i dansk fængsel, men under tysk bevogtning. Forhøret foretages alene af en tysk krigsretsdommer.« ${ }^{21}$

Altså ingen medvirken af danske embedsmænd.

Svenningsen orienterede kl. 19 departementschef Aage Svendsen i Justitsministeriet om tyskernes svar, som Svendsen accepterede. Svendsen bad Harald Petersen sætte sig i forbindelse med Jänz. Om aftenen, på samme tidspunkt som fangerne var ankommet fra Aabenraa og Haderslev og indsat i den tyske arrest i Kastellet, forsøgte Harald Petersen forgæves at træffe Jänz på Hotel Cosmopolite. Da Harald Petersen ikke kunne få fat i Jänz, forsøgte Svenningsen at få forbindelse med Kanstein, hvilket først lykkedes den 1. maj om morgenen. Kanstein udtrykte sin beklagelse over, at Jänz tilsyneladende ikke ville mødes med Petersen aftenen før, og han lovede straks at 
tage sagen $\mathrm{i}$ egen hånd for at bringe den i overensstemmelse med de indgåede aftaler. Dette løfte skulle umiddelbart betyde, at de arresterede skulle flyttes til dansk fængsel, men under tysk bevogtning!

Kansteins løfte skulle efterfølgende vise sig at komme for sent for to af de arresterede.

\section{Situationen i Sønderjylland fra 9. april til 30. april 1940}

Tre dage efter at tyske tropper havde overskredet den dansk-tyske grænse, pågreb det tyske militær 12. april om morgenen tidligere forsikringsagent Jens Dons, Kolding og måleraflæser ved Midtsønderjyllands Elselskab (MSE) Alfred Petersen, Strandelhjørn, på deres bopæl. Straks efter anholdelsen blev de, uden advisering af danske myndigheder, kørt til Flensborg og fængslet. Reelt var der tale om en kidnapning. Den 15. april startede forhørene af dem.

Som en direkte konsekvens af disse afhøringer og efter krav fra Fregattenkapitän Howoldt blev følgende personer anholdt af dansk politi i Sønderjylland den 20. og 21. april, sigtet for at stå i betalt tjeneste hos den engelske Secret Service. De blev alle indsat i arresten i Aabenraa:

1. Skræddermester Hans Peter Lythje, Aabenraa, født 18. juli 1894.

2. Købmand Nicolaus Nissen Wind, Bov, født 7. april 1877. Wind blev anholdt på sin bopæl kl. 5 om morgenen. Han nægtede sig skyldig i spionage, gav tilladelse til ransagning, men politiet fandt intet af interesse. Han ankom til arresten i Aabenraa, men nægtede at kende andre af de fængslede. Wind oplyste dog, at han kendte Jens Dons, men at han ikke havde mødt ham siden 1934.

3. Journalist Carl Johan Bech, Aabenraa, født 8. januar 1906. Bech blev anholdt på sin bopæl Nr. Chaussé $13 \mathrm{~A}$ i Aabenraa kl. 5 om morgenen af kriminalassistenterne Egeskov og Jacobsen. Under ransagningen indfandt kriminalassistent Troelsen sig ledsaget af oberstløjtnant Uthhoff fra Inf. Reg. Nr. 26 Standort Flensburg. Uthhoff meddelte Jacobsen, at han af de militære myndigheder i København havde fået besked om at henvende sig hos politimesteren i Aabenraa for at assistere ved anholdelser og sikre eventuelle beviser.

4. Færgemand Simon Sørensen Madsen, Kongsmark, Rømø, født 21. oktober 1898. Madsen var skibsfører på postbåden mellem Ballum Sluse og Kongsmark. På grund af de besværlige rejseforhold til Rømø blev Madsen først anholdt den 21. april kl. 12.30 og herefter ført til arresten i Aabenraa. 
5. Redaktør Viggo Peter Johannes Lausten, Tønder (tysk statsborger), født 31. juli 1904.

Den 26. april anholdt politiet følgende personer:

6. Gårdejer Emil Fries, Gøtterup ved Toftlund, født 12. januar 1883 i Altona. Fries var først blevet dansk statsborger i 1936. Han blev anholdt på bopælen kl. 7 af kriminalassistenterne Frihagen og Lindholm fra politiet i Toftlund. I rapporten fra anholdelsen oplyste Lindholm, at det var kendt, at Fries var tilsluttet Frits Clausens DNSAP.

7. Gartner Lorentz Hansen Jepsen, Frederikskog ved Højer, født 14. december 1915. Jepsen blev anholdt på sin bopæl kl. 7 om morgenen. Han nægtede sig skyldig i sigtelsen for spionage. Han erkendte at have mødt Byron i Ribe, og at han havde lavet en beretning om tyske veje og kornvækst. For denne beretning havde han modtaget $100 \mathrm{kr}$. af Dons.

8. Kriminalassistent Peter A. Dons, Haderslev, født 11. december 1876.

Fries og Jepsen blev indsat $\mathrm{i}$ arresten i Aabenraa, Peter Dons i arresten i Haderslev.

Igen efter tysk anmodning blev tre personer anholdt i Sønderjylland den 28. april:

9. Snedkermester Hans Thomas Lützen, Bredebro, født 16. februar 1868. Lützen blev anholdt på sin bopæl. Ved den efterfølgende ransagning blev der ikke fundet noget af interesse.

10. Maskinmester Carl Lauritz Peter Engberg, Trappen ved Grăsten, født 22. februar 1883. Han skulle have været anholdt 26. april, men da politiet kom til hans bopæl kl. 7, oplyste hans hustru, at manden, der var maskinmester på S/S Carl Clausen, var på sejlads med kreaturer og svin mellem danske og tyske havne. Hustruen oplyste, at hun kendte Jens Dons flygtigt, idet hendes mand havde været underagent i Forsikringsselskabet Hafnia. Engberg blev anholdt af kriminalassistenterne J. A. Jensen og C. Mønnicke ved skibets anløb i Gråsten Havn 28. april kl. 21.

11. Rentier Georg Heinrich Nikolaus Julius Leonhardt Sager, Haderslev, født 24. marts 1879. Sager, der var tysk statsborger, boede egentlig i Slesvig by, hvor han ejede en ejendom, men i en periode havde han boet Storegade 78, 2. sal, i Haderslev. Ved politiets ankomst om morgenen var Sager ikke til stede. En nabo oplyste, at Sager var taget til Rømø 20. april. Sager blev anholdt samme dag kl. 14 i sit 
sommerhus på Rømø. I et senere håndskrevet brev oplyste Sager, at han i 1936 havde fået frataget sin danske arbejdstilladelse af kriminalassistent Peter Dons, som anså ham for at være tysk spion. ${ }^{22}$

De tre anholdte blev, som de syv andre arresterede, indsat $i$ arresten i Aabenraa. I samme sag blev translatør Johan Jørgen Lomholdt Pedersen, Gentofte, arresteret 28. april af politiet i København og indsat i Vestre Fængsel.

Kommunikationen foregik pr. fjernskriver fra Rigsregistraturen i København til politimester Aage Agersted i Aabenraa. Den 20. april kl. 16.40 meddelte Rigsregistraturen: "De er fængslet i 7 dage for sammen med Jens Dons at have virket for det engelske efterretningsvæsen." 19. april, da tyskerne krævede de sigtede anholdt, ønskede de, som tidligere nævnt, straks at få de arresterede udleveret og sendt til København, men dagen efter meddelte Rigsregistraturen, at statsadvokat Harald Petersen havde beordret, at de arresterede skulle forblive i Aabenraa »med mulighed for tysk afhøring, med nærværelse af dansk politimand. Arrestanterne må ikke flyttes uden tilladelse fra Harald Petersen «.

Denne meddelelse har politimester Agersted tilsyneladende opfattet således, at der ville komme tyske militærpersoner til Aabenraa for at afhøre de arresterede, for 22. april kl. 16.15 telegraferede han til Kobenhavn, at singen tysk militærperson har endnu henvendt sig."

Den 24. april kl. 11 telegraferede Agersted til Harald Petersen, efter at have været i kontakt med politiet i Flensborg: "Chefen for kriminalpolitiet i Flensborg Hermannsen kender intet til sagen og har ikke fået ordre til undersøgelser. Han erklærede, at sagen hører under Kommandostelle København."

De fem, som blev fængslet 20. april, fik af Københavns Byret den 27. april deres fængsling forlænget til 4. maj.

I alt 26 gange glødede fjernskriveren mellem København og Aabenraa i perioden fra 19. april til 4. maj 1940. Efter møder på højeste politiske plan i København med den tyske besættelsesmagt gav Harald Petersen 28. april politimestrene i Aabenraa og Haderslev ordre til, at de 11 arresterede skulle udleveres til tyskerne. Kl. 7 om morgenen den 30. april blev de ti i Aabenraa afhentet af tysk militær. En Feldwebel kvitterede over for politiet i Aabenraa for modtagelsen af fangerne, som to og to i fem små militærbiler blev kørt fra Aabenraa.

Peter A. Dons skulle med fra Haderslev, men han blev dog transporteret i Haderslev Politis egen bil. Kl. 16.45 ankom fangerne til Ka- 


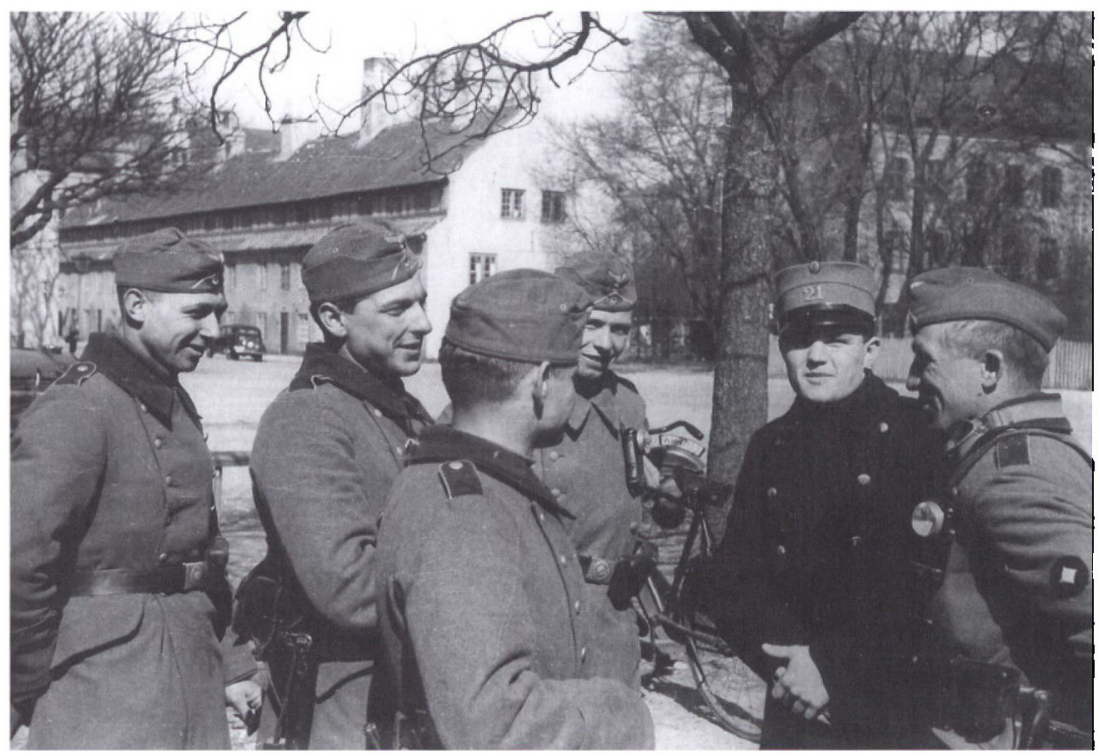

Kastellet $i$ Kobenhawn blev indtaget af de tyske tropper om morgenen den 9. april 1940. Frem til befrielsen $i$ maj 1945 blev anlagget blandt andet brugt som krigsret og arrest. På billedet, der er taget den 9. april om morgenen, ses tyske soldater $i$ fredelig samtale med en dansk soldat - formentlig et medlem af den vagtstyrke, der stationeret dér den 9. april. Foto: Frihedsmusect.

stellet i København. Efter at have afleveret deres personlige genstande blev de indsat $i$ hver sin celle. ${ }^{23}$

Det er værd at bemærke, at politichefen i Flensborg, Hans Hermannsen - senere kendt under navnet Gestapo-Hermannsen - den 24. april havde meddelt politimester Agersted, at han intet havde med sagen at gøre. Han blev i slutningen af april 1940 overflyttet fra Flensborg til Det tyske Gesandtskab på Dagmarhus i København med den begrundelse, at man havde brug for en person med indgående kendskab til grænseområdet. ${ }^{24}$

Et sammentræf, der må give anledning til at stille spørgsmålet: Kan man virkelig forestille sig, at Hermannsen, der ankom til København stort set på samme tidspunkt som de arresterede, ikke på en eller anden måde var involveret $\mathrm{i}$ afhøringerne af fangerne $\mathrm{i}$ Kastellet med det indgående kendskab, han havde til afhøringerne af Dons og Alfred Petersen i Flensborg? 
Kastellet 1. maj 1940

Den 16. maj 1940 sendte statsadvokat Harald Petersen følgende indberetning til Justitsministeriet:

"De arresterede blev afhørt den 1. maj 1940. Efter endt afhøring blev Bech, Madsen, Lützen og Engberg løsladt direkte af den tyske værnemagt. Lythje, Wind og Jepsen blev kl. 18.45 den 1. maj overgivet til de danske myndigheder til videre foranstaltning. Statsadvokat Harald Petersen løslod Wind og Jepsen henholdsvis den 9. og 11. maj 1940. Sager blev løsladt direkte af tyskerne den 8. maj 1940. Lausten og Peter A. Dons er afgået ved døden i Kastellet, førstnævnte som følge af selvmord, genpart af det foretagne ligsyn vedlægges. Ligsynsforretningen vedr. Dons er endnu ikke afsluttet, men genpart vil senere blive fremsendt. De tyske afhøringer af Fries og Lomholdt Pedersen er endnu ikke afsluttet. Fries er på grund af dårligt helbred den 4. maj indlagt $\mathrm{i}$ Vestre Fængsels sygeafdeling. ${ }^{25}$

Emil Fries indrømmede på et retsmøde 24. maj, at han vidste, hvem chefen for The British Passport Office indtil 1929, Hudson, var. Han benægtede at have fået penge af Dons for at spionere. Fries og Lomholdt Pedersen blev losladt 4. juni 1940. Bech, Madsen, Fries, Engberg og Lomholdt Pedersen var fortsat formelt sigtet for overtrædelse af straffelovens $\S 105$, men 4 . marts 1941 blev alle sager frafaldet på grund af bevisets stilling. ${ }^{26}$

\section{Forsikringsagent Jens Dons}

Oplysningerne om Dons' agentvirksomhed for Secret Service bygger på de afhøringer, som begyndte i Flensborg 15. april 1940 og som fortsatte efter udleveringen til Opdagelsespolitiet i København 5. august $1940 .{ }^{27}$

Under et ophold på Rømø i 1924/25 lærte Dons franskmanden Paul Cramer at kende. Cramer var ansat ved Det franske Generalkonsulat i København. Hans far var fra Rømø, og der var stadig familie på øen. Cramer overtalte Dons til at kortlægge nogle militære anlæg på øen Sild. Dons skaffede oplysningerne, men Cramer havde ikke midler til at betale Dons. I stedet henviste han ham til The British Passport Office i København. Dons henvendte sig på kontoret i Bornholmsgade 3, hvor man havde modtaget informationer om ham fra Cramer. Han blev modtaget af sekretæren, frk. Lucy Bracken, der 
præsenterede ham for kontorets chef Hudson. Udover arbejdet med at udstede pas var kontoret også ramme for Secret Service. Det blev aftalt, at Dons mod betaling skulle sende beretninger om forhold nord og syd for den danske grænse til Hudson.

I perioden 1925-1929 fik Dons ikke noget fast honorar. I 1929 blev Hudson afløst af kaptajn Cyrus Smith, der fremover skulle modtage Dons' beretninger. Arbejdet for englænderne kombinerede han med sit job som rejseleder for Cunard White Star. Efter de tyske nazisters magtovertagelse i 1933 kom "ansættelsesforholdet « i fastere rammer, og Dons fik nu et månedligt honorar på $300 \mathrm{kr}$. plus præmie for særligt vigtige indberetninger.

I 1934 hvervede Dons generalagent i forsikringsselskabet Teutonia, Flensborg, og meddeler til Modersmålet i Haderslev Hans Petersen, Tinglev (født 4. juli 1865 i Gabøl - død 23. april 1937 i Tinglev) som efterretningsagent. Hans Petersen modtog et månedligt honorar på $450 \mathrm{kr}$. Han var kendt med landsdelen fra Kongeåen til Ejderen og var formand for Danske Forsvarsbrødres afdeling $\mathrm{i}$ Tinglev. ${ }^{28}$

I 1933/34 blev Dons kaldt til Kobenhavn. Smith gav ordre til, at han skulle kontakte landmand Emil Fries i Gotterup ved Toftlund og redaktør Viggo Lausten i Tønder, sidstnævnte fordi Smith ønskede at hverve en agent på vestkysten. ${ }^{29}$ Dons, der kendte Lausten fra besøg på redaktionen i Tønder, fik i opdrag at arrangere et møde mellem Lausten og Smith i Esbjerg. Det lykkedes at overtale Lausten, og de kørte til Esbjerg for at mødes med Smith på Hotel Spangsbjerg. Lausten og Smith skulle have talt sammen i tre timer. Dons påstod, han ikke deltog i samtalen.

Da Dons på et senere tidspunkt fik en for ham uløselig opgave vedr. de militære anlæg på øen Helgoland, gik han til Lausten, som efter Dons' udsagn straks tegnede anlæggene for ham: "Jeg erindrer at samtlige batterier var indtegnet og batterier angivet med kaliber og rækkevidde, herudover tegnede han underjordiske tunneller og ammunitionslager, « sagde Dons under forhøret. ${ }^{30}$

Lausten oplyste til Dons, at han havde fået samme opgave af Smith, og Dons fik derfor det indtryk, at hans opgave skulle være en slags kontrol af Lausten. Lausten skulle også have hjulpet Dons med at lave en $40 \times 60 \mathrm{~cm}$ skitse over havnen i List på Sild. Lausten fik efter Dons' udsagn $200 \mathrm{kr}$. i honorar om måneden udbetalt direkte fra englænderne.

Af afhøringerne fremgår det, at det var Dons' opfattelse, at Lausten 
var en meget brugbar efterretningsmand, fordi han som tysk statsborger havde gode muligheder for at rejse ind og ud af Tyskland. Dons oplyste, at han ikke havde været i Tyskland i perioden fra $1927 \mathrm{og}$ indtil anholdelsen i april 1940. Under den forste afhøring i Flensborg oplyste Dons, at han primært fik sine oplysninger fra Kieler Neueste Nachrichten og Hamburger Fremdenblatt samt fra Alfred Petersen, Hans Peter Lythje og Viggo Lausten.

Udover de navne, som allerede er nævnt, og som Dons påstod, han havde hvervet som agenter, indeholder forhørsprotokollen mere end 30 navngivne personer med bopæl såvel nord som syd for den dansktyske grænse. Disse personer skulle i større eller mindre grad have forsynet Dons med informationer. Man kan få indtrykket, at Dons har nævnt disse personer i flæng for at tilfredsstille forhørslederne.

Om sin broder Peter oplyste Dons, at han hvervede ham i slutningen af 1920'erne under dæknavnet »Der kleine Vetter « og betalte ham $50 \mathrm{kr}$. om måneden for at levere beretninger om politik og forbindelser mellem danske og tyske kommunister. Jens Dons præsenterede broderen for deres nye engelske kontaktmand Byron i Haderslev i begyndelsen af 1937. Efter dette møde fik Peter Dons forhøjet sit honorar til $100 \mathrm{kr}$. månedligt, og beløbet fik han nu direkte fra Byron. Peter Dons fik senere, efter at have produceret en større rapport om troppebevægelser i Tyskland, forhøjet sit månedlige honorar til 400 kr., og under broderens sygdom i 1938 varetog han dennes efterretningsopgaver. Jens Dons gjorde under afhøringerne meget ud af at pointere, at årsagen til broderens medvirken var et ulykkeligt ægteskab og hustruens store privatforbrug. ${ }^{31}$

I 1938 og 1939 mødtes Jens Dons og Byron 5-6 gange i København, og $\mathrm{i}$ den periode fik Dons en del af sit honorar indsat på en konto i England. Midlerne skulle være til rådighed, hvis forholdene udviklede sig, så flugt blev nødvendig. Fra 1939 måtte Dons på grund af den tilspidsede situation ikke længere sende sine beretninger direkte til Paskontoret. Han brugte i stedet dækadresser.

Som tidligere omtalt var Dons under observation af SIPO fra oktober 1939. Sikkerhedspolitiets chef, Strøbech, havde kontakter til Gestapo i Berlin og Kiel, og det er ikke usandsynligt, at Strøbech og tysk politi i slutningen af 1939 har drøftet overvågningen af Dons og Petersen. Korrespondance fra oktober 1939 med Svenska-Amerikalinien og Cunard White Star viste, at Dons planlagde at flygte til USA. Han indhentede tilbud på afrejse både i november og januar, og Cu- 
nard rykkede den 20. november 1939 for, om beslutning var truffet. ${ }^{32}$ Han nåede ikke at flygte, men blev 12. april $1940 \mathrm{kl} .9$ anholdt og kørt til Flensborg og fængslet dér.

Det uafklarede spørgsmål er: Hvordan kunne tyskerne så kort tid efter besættelsen have viden om Dons' aktiviteter? Var det fra de tætte kontakter der var allerede i 1939? Var det fra de ikke tilintetgjorte akter på Politigården i København? Eller havde SIPO-medarbejdere den 10. eller 11. april forsynet tyskerne med oplysninger? Eller havde Gestapo allerede før besættelsen modtaget indberetninger om Dons og Alfred Petersen fra tyske spioner i Nordslesvig?

Det tyske politi gennemførte afhøringer af Dons den 15., den 29. april og den 22. maj. Journalist G.S. Tscherning, korrespondent ved Flensborg Avis, skrev 27. august $1945 \mathrm{i}$ et brev til Justitsministeriet: "Spionen Dons blev ført til Flensborg og efter sigende frygtelig tilredt. Det hævdes, at han var sindssyg, da han blev udleveret til Kobenhavns Byret."

I breve, som Dons sendte til familien fra fængslet i Kobenhavn, skrev han dog i modsætning til Tscherning, at han var blevet behandlet godt i Flensborg. Men brevene var naturligvis også censureret. At Dons skulle have været udsat for tortur i fængslet i Flensborg, bekræftes af den danske provst i Flensborg, Waage Beck, som i juni 1940 havde en skriftemålssamtale med Dons, medens han var fængslet: "Dons var blevet sådan mishandlet, at de tyske fængselsmyndigheder ikke turde nægte ham en fortrolig samtale med en præst. « ${ }^{33}$

Der er næppe tvivl om, at Dons blev udsat for en hårdhændet behandling hos Gestapo i Flensborg. Ud over fysisk vold har den psykiske vold sikkert også tæret på Dons' i forvejen skrøbelige helbred.

Petersens og Dons' fængselsophold i Flensborg kom til at vare i næsten fire måneder, uagtet at Renthe-Fink i et brev 6. maj til udenrigsminister von Ribbentrop skrev, at afhøringerne i Flensborg var afsluttet, og at det var hans indstilling, at man skulle opfylde et dansk ønske om at få de to udleveret til dansk retsforfølgning. Først 5 . august $1940 \mathrm{blev}$ Dons og Petersen overført til videre retsforfølgning ved Københavns Byret og i et grundlovsforhør dagen efter fængslet. Den syge Dons blev 9. august 1940 indlagt på Kommunehospitalets Psykiatriske Afdeling, hvor han var indtil 9. oktober 1940. Under sin indlæggelse skrev Dons et brev til kongen. Det er dog uvist om brevet blev sendt: »Jeg har ikke været $\mathrm{i}$ Tyskland siden 1927. I min enecelle i Flensborg så jeg som ugerne gik gruelige ansigter og hørte dag og nat skrækkelige stemmer med frygtelige beskyldninger og trusler mod mig. " ${ }^{34}$ 


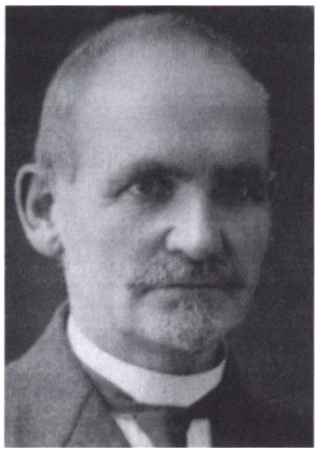

Forsikringsagent Jens Dons havde arbejdet for den britiske efterretningstjeneste siden $1920^{\prime}$ erne. Han blev arresteret den 12. april 1940 og fangslet $i$ Flensborg. Under afhoringerne belastede Jens Dons blandt andre Viggo Lausten, redaktor af Flensborg Avis' aflægger $i$ Tonder. Ifølge Dons skulle Lausten have leveret oplysninger om de militære anlæg på Helgoland. Jens Dons blev idønt fem års fængsel ved Københavns Byret. Hans helbred var dårligt, og han døde på Horsens Sygehus den 18. juli 1942. Foto: Odd Fellow-logen Holger Danske, Esbjerg.

Med udgangspunkt i hans tilståelse ved Retten i Flensborg blev Dons i perioden 16.- 24. oktober 1940 afhort fem gange. Den 12. november havde Dons i et brev til politiadvokat Beck bedt om, at hans sag blev fremmet. Brevet virkede, og 11. december 1940 blev Jens Dons ved Københavns Byret idømt fem års fængsel for spionage. Dons bad efter dommen indtrængende om at få lov til at afsone straffen i Horsens. Så havde familien bedre muligheder for at besøge ham. ${ }^{35}$ Den 27 . december 1940 blev han overflyttet til Statsfængslet i Horsens. Tyskerne var dog ikke helt færdige med ham. Den 17. oktober 1941 indberettede fængselsinspektøren, at en SS-Sonderführer Molzen, Silkeborg, den 13. oktober havde anmodet om lov til at afhøre Dons.

Dette blev afslået på grund af Dons' dårlige helbred, men den 15. oktober indfandt Kriegsgerichtsrat Gersdorff og førnævnte Molzen sig for at afhøre fange nr. 90 Dons om hans kendskab til en person, som tyskerne ønskede at strafforfølge. I overværelse af fængselslægen, inspektøren og viceinspektøren blev Dons afhørt som vidne. Inspektøren ved Statsfængslet i Horsens noterede: "I starten rolig og fornuftig, senere grædende og klynkende, - afhøringen varede 20 minutter. « $^{36}$

Stadig fængslet døde Jens Dons på Horsens Sygehus den 18. juli 1942.

\section{Mejerimontør og måleraflæser Alfred Sofus Ebbe Petersen, Strandelhjørn}

Alfred Petersen havde levet en omtumlet tilværelse med mange forskellige jobs $i$ ind- og udland. Blandt andet var han på et tidspunkt ejer af et mejeri i Kiel, mejerimontør i Rusland og redaktør i Aarhus. 
Da Alfred Petersen i februar/marts 1937 besøgte sin dødssyge bror Hans i Tinglev, mødte han Jens Dons og Byron. Petersen troede, at Byron var amerikaner med en forretning i København, hvorfra han solgte dagblade. Efter sygebesøget drøftede de tre mulighederne for et samarbejde. Alfred Petersen skulle på rejser i Tyskland indsamle oplysninger om industrielle og kulturelle forhold. Efter en prøverejse til Tønning i april 1937 afleverede Petersen på Haderslev Banegård sine observationer til Dons i en lukket kuvert. Rejsen og rapporten må have været tilfredsstillende, for Petersen fik efterfølgende mange opgaver i Tyskland, hvor han nød godt af sit omfattende kontaktnet.

En af hans forste opgaver var at finde ud af, om tyskerne i Kiel eksperimenterede med motorer til undervandsbåde. Ud over efterretninger fra Kiel sogte han informationer i Hannover, Wilhelmshaven, Cuxhaven og Neustadt. I 1937 onskede Byron i lyset af den faretruende udvikling i Europa at udvide aktiviteterne. Dons, Byron og Petersen mødtes i maj på Hotel Vasegaarden i Fredericia, hvor Petersen fik til opgave at skaffe tre underagenter.

Aktivitetsforøgelsen medførte en øjeblikkelig lønforhøjelse til 400 kr. månedligt, der blev sendt til hans nyoprettede postboks nr. $56 \mathrm{i}$ Aabenraa. Udover honoraret fik Petersen 300 kr., så han kunne betale sine underagenter. Efterretningerne skulle ikke sendes til Paskontoret, men til dækadressen: W. Burmann, Kiosk nr. 11, Lille Triangel i København.

De tre mødtes igen på Hotel Vasegaarden i juli 1937, og Petersen fik i opdrag at rejse til Neustadt og søge informationer om en militærskole. Det var dog umuligt for ham at komme i nærheden af skolen, da han følte sig iagttaget af et par SA-folk. I 1937-38 var han flere gange i København. I august 1938 mødtes han med Byron og en anden person på Cafe de la Reine tæet ved Dronning Louises bro. Petersen fik besked om at rejse til Hamborg for at skaffe informationer om krydseren Karlsruhe samt undersøge, om der blev bygget undervandsbåde på det store værft Blohm \& Voss.

Alfred Petersen fortsatte sine aktiviteter med uformindsket styrke indtil et møde med Byron i København i starten af august 1939. Mødet, der skulle blive det sidste mellem de to, fandt sted på Hovedbanegården, og Byron onskede, at Petersen skulle rejse til Wilhelmshaven for at undersøge, hvilke og hvor mange skibe der lå i havnen. På grund af den tilspidsede situation i Tyskland turde Petersen ikke rejse, men Byron pressede ham og oplyste, at rejsen var meget vigtig. 
Petersen accepterede og fik udbetalt $700 \mathrm{kr}$ i a conto honorar. Resten, $300 \mathrm{kr}$., forfaldt, når beretningen var afleveret. Han turde dog ikke gennemføre rejsen, men fabrikerede en fiktiv beretning, som han sendte til kiosken på Lille Triangel. Han hørte ikke fra Byron og modtog heller ikke de $300 \mathrm{kr}$. I december 1939 hentede Petersen brevet i København, hvor det lå uafhentet.

Under forhøret i Københavns Byret 18. oktober 1940 fortalte Petersen om en rejse til Lübeck, som fandt sted 25. og 26. juli 1939, og han fastholdt samtidig, at rejsen til Wilhelmshaven aldrig var blevet gennemført. Han påstod, at han ikke havde været i Tyskland siden midten af august 1939, hvilket bekræftes af hans to pas.

Efter at SIPO i oktober 1939 havde modtaget informationer om Alfred Petersen og Jens Dons' efterretningstjenester til fordel for England, blev de tæt overvåget af SIPO. Overvågningen gav ikke noget bevis for, at Alfred Petersen fra slutningen af august 1939 og frem til den tyske besættelse udførte efterretningsvirksomhed for Secret Service. Petersen bekræftede under forhøret den 20. august 1940, at modet 19. oktober 1939 i Kolding mellem Dons og ham selv fandt sted som beskrevet af SIPO.

Alfred Petersen blev anholdt af tysk militær på sin bopæl i Strandelhjørn 12. april 1940. Han blev kørt til Flensborg og fængslet. Ligesom Jens Dons blev han afhørt første gang 15. april 1940. Da der ikke er fundet en afskrift af forhørsprotokollen fra Flensborg, bygger udsagnene på afhøringerne foretaget af Københavns Opdagelsespoliti i august 1940 .

Den 5. august 1940 afleverede politibetjent Appel i Kruså Alfred Petersen og Jens Dons til politiet i København, og efter et grundlovsforhør 6. august blev de fængslet. Alfred Petersens sag begyndte ved Byretten den 8. august. Han oplyste over for retten, at han var indstillet på at gentage den tilståelse, som han i april havde aflagt til Retten i Flensborg.

Statsadvokat Harald Petersen var inden retssagerne overbevist om, at der på grundlag af de foreliggende akter forelå begrundet mistanke mod Jens Dons og Alfred Petersen om spionage, og at ligeledes Peter A. Dons var impliceret. For så vidt angår Peter A. Dons var dette en gentagelse af SIPO's konklusioner fra 4. november 1939. ${ }^{37}$

Den 31. august 1940 fik Alfred Petersen sin dom ved Københavns Byret. Den lød på fem års fængsel minus 94 dage, som var udstået. Petersen, der mente at dommen var for hård, ankede afgørelsen til Østre 
Landsret, som den 21. oktober stadfæstede byrettens dom. I sommeren 1942 søgte Petersen om benådning. Ansøgningen blev behandlet af $\mathrm{Ge}-$ richtsrat H. Johannsen for Gericht des Befehlhabers der Deutschen Truppen in Dänemark, som 21. september 1942 afslog ansøgningen. Den 29. maj 1943 behandlede krigsretten en fornyet ansøgning og tiltrådte benådning. I et brev fra Justitsministeriet blev det oplyst, at Hans Majestæt Kong Christian X den 2. juni havde bifaldet ansøgningen i anledning af den forestående grundlovsdag. Fange nr. 31 i Statsfængslet i Vridsløselille Alfred Petersen blev løsladt 5. juni 1943.

Efter sin løsladelse tog Petersen toget til Over Jerstal, hvor han blev hentet af sin svoger sondag formiddag. Samme dag var familien, store som små, samlet i Strandelhjørn for at byde ham velkommen hjem, og selv om han var noget svækket af fængselsopholdet, var han ved godt mod. ${ }^{38}$

Alfred Petersen døde i Strandelhjørn 6. januar 1947 og er begravet ved siden af sin hustru i hendes familiegravsted på Bevtoft kirkegård. I en omtale ved hans død blev spionsagen perifert nævnt: "Straks efter besættelsen blev Alfred Petersen arresteret og ført til Tyskland. Senere sad han i Vridsløselille, hvorfra han blev løsladt i 1943. « ${ }^{39}$

Næsten to år efter krigens afslutning var der åbenbart ingen interesse hos pressen for at undersøge sagen nærmere.

\section{Skræddermester Hans Peter Lythje, Aabenraa}

Kort før generalagent Hans Petersens død i april 1937 havde Jens Dons hvervet skræddermester Hans Peter Lythje, Aabenraa, som efterretningsagent. Lythje blev i starten aflønnet af de ekstrapenge, som Dons fik af Smith. Kort efter at Byron havde afløst Smith, mødtes Byron og Lythje i Vamdrup, og efter dette møde fik han betalingen direkte fra Byron. Lythjes hovedopgave var at indsamle oplysninger om samtlige flyvepladser i Nordtyskland, et arbejde som blev lettet af, at Lythje havde en del familiemedlemmer $i$ Tyskland. Han kunne derfor rejse mellem Sønderjylland og Tyskland uden at vække opsigt.

Lythje blev anholdt og hans bolig Slotsgade 25 ransaget kl. 5 om morgenen den 20. april 1940. I forbindelse med husundersøgelsen fandt man en ubrugt kuvert med adressen $» H r$. C. Broholm. Kiosk nr. 1, Kgs. Nytorv, København«. Lythje nægtede ethvert kendskab til kuverten og mente, at den kunne have ligget der fra den forrige beboer af ejendommen. Man fandt også en papirlap påfort "S. 5a.«. Lythje 
oplyste, at det var agenturnummeret for Forsikringsselskabet Dannebrog. Han havde i november 1939 overtaget agenturet fra skomagermester Boysen.

Efter anholdelsen og ransagningen blev Lythje ført til politistationen i Aabenraa og præsenteret for sigtelsen om spionage. Han nægtede sig skyldig og gentog, at han intet kendte til den tomme kuvert.

Hans Peter Lythje tilhørte det tyske mindretal, men deltog ikke i politiske møder. Han var dog efter deltagelse i 1. Verdenskrig medlem af Kammeradschaftlicher Verband ehemaliger Deutscher Soldaten og næstformand i den lokale samariterforening. Så helt uden omgangskreds var han ikke.

Lythje nægtede ethvert kendskab til tre af de andre fængslede Wind, Madsen og Vegeol Austen (fejlskrivning af Viggo Lausten). Han oplyste, at hans indtægter stammede fra invalidepension, skrædderi og forsikringsagenturet. Han blev 30. april 1940 sammen med de andre fængslede i Aabenraa afhentet og kørt til Kastellet i København. Uanset at Lythje ved anholdelsen havde nægtet sig skyldig, tilstod han under afhøringerne i Kastellet 1. maj 1940, at han siden 1937 havde samarbejdet med Jens Dons og skaffet efterretninger til Secret Service. Han oplyste, at hans engelske kontaktmand hed »Beirum«, hvilket sikkert er en fejlskrivning af Byron. Lythje indrømmede over for krigsretten, at han havde modtaget penge af Byron for oplysninger om bygning af krigsskibe og beliggenheden af nordtyske flyvepladser.

Efter tilståelsen over for den tyske krigsret blev Lythje den 7. maj udleveret til de danske myndigheder på betingelse af, at han blev tiltalt for spionage ved en dansk ret. Han skulle være fængslet indtil domsafsigelsen. Statsadvokat Harald Petersen oplyste i maj over for Justitsministeriet, »at Wind og Jepsen var blevet løsladt. Lythje, som havde tilstået omfattende spionage til fordel for englænderne, og af Jens Dons modtaget vederlag på i alt ca. $7.000 \mathrm{kr}$. ville få sin sag behandlet ved Københavns Byret « ${ }^{40}$

Jens Dons havde i forbindelse med forhoret i Flensborg den 15. april 1940 oplyst, "at Lythje hurtigt blev den bedste agent ved grænsen. Han havde på grund af mange tyske ordner adgang overalt, og Lythje modtog god betaling for oplysninger om nordtyske flyvepladser.« Jens Dons oplyste også, »at såvel Alfred Petersen som Lythje havde haft agenter i Tyskland, men navnene kendte Dons ikke. ${ }^{41}$

Den 23. maj 1940 idømte Københavns Byret Lythje fem års fængsel for spionage til fordel for England. Han blev løsladt i sommeren $1943 .{ }^{42}$ 


\section{Redaktør Viggo Peter Johannes Lausten, Tønder}

Viggo Lausten var tysk statsborger, men tilhørte det danske mindretal. Han var søn af faktor på Flensborg Avis, Laust Kaspar Lausten. I januar 1934 blev han gift med Karoline Clausen, datter af en dansksindet skibsarbejder fra Flensborg, og i maj 1939 blev deres datter Tove født. ${ }^{43}$

Lausten tog studentereksamen fra Sorø Akademi i 1920-22. Han fortsatte de spejderaktiviteter, som han havde påbegyndt i Flensborg i 1919, medens han var i Sorø. Efter at han i 1922 var vendt tilbage til Flensborg, blev han igen meget aktiv inden for spejderbevægelsen. I en periode var han tropsfører for Sankt Knuds Trop, og i 1927 blev han udnævnt til korpschef. I 1922 kom Lausten i journalistlære på Flensborg Avis med redaktør Ernst Christiansen som chef. ${ }^{44}$ I 1933 blev han redaktor af Vestslesvigs Tidende, Flensborg Avis' lokaludgave i Tønder.

Det danske spejderarbejde i Flensborg afveg på mange punkter fra traditionelt dansk spejderarbejde. Det nationale var i højsædet, hvorfor danskerne i 1919 afslog et tysk forslag om at samle de danske og tyske spejdere i én trop. I 1932 var der en heftig diskussion blandt Flensborgs danske spejdere over 17 år, de såkaldte rovere, og man besluttede, at patruljen ikke måtte beskæftige sig med tysk politik. Man skulle alene koncentrere sig om at fremme det danske spejderarbejde i Flensborg. Denne beslutning blev kun tiltrådt af seks rovere, heriblandt Lausten. De øvrige betragtede man derefter som udmeldt. ${ }^{45}$

Om disse hændelser på en eller anden måde havde betydning for den dramatiske situation i Kastellet syv år senere kan ikke dokumenteres, men samtidig med nazisternes overtagelse af magten i Flensborg forlod Lausten byen og flyttede til Tonder. I 1934-35 var han sammen med andre tøndringer medlem af Sct. Georgs Gildet i Aabenraa. Den 15. september 1935 fik de tilladelse til at oprette deres eget Tøndergilde. Fra 1936 og indtil sin død var Lausten gildemester.

Efter krav fra Fregattenkapitän Howoldt blev Lausten 20. april 1940 kl. 5 om morgenen anholdt på sin bopæl i det tidligere Marschbahnhofshotel i Jernbanegade i Tønder. Sigtelsen lød på overtrædelse af straffelovens $\S 105 .{ }^{46}$ Lausten blev kørt direkte fra bopælen i Tønder til arresten i Aabenraa. Københavns Byret afsagde samme dag fængslingskendelse over Lausten. Denne blev forlænget 27. april til udløb 4. maj. I arresten i Aabenraa skrev Lausten i sin dagbog: »Vel nok efter henstilling fra den tyske værnemagt er der afsagt fængsels- 
kendelse over mig, uden at jeg har fået den mindste lejlighed til at udtale mig om noget som helst. ${ }^{47}$

Det eneste, Lausten og de andre fængslede kunne få at vide, var, at de var sigtet for spionage, og at det var Jens Dons, der havde angivet dem. ${ }^{48}$

Karoline Lausten besøgte sin mand i arresten i Aabenraa den 22. april. I et brev til redaktør Ernst Christiansen udtrykte hun stor optimisme med hensyn til mandens snarlige løsladelse. Hun skulle nok klare kontorets opgaver så længe. ${ }^{49}$ Efter at fængslingen den 27 . april var forlænget med yderligere en uge, sendte Lausten et kort til en af sine gode venner i Tønder: "Min sag står godt, og jeg regner med at komme hjem til Tønder om få dage."

Det var en optimistisk hilsen, som ikke tydede på, at Lausten så fremtiden i mode med stor ængstelse.

Sammen med de ni andre, som sad fængslet i Aabenraa, blev Lausten med accept fra statsadvokat Harald Petersen 30. april kl. 7 udleveret til en tysk Feldwebel og kørt til Kastellet. Sammen med Peter A. Dons, der kom direkte fra Haderslev, ankom de 11 arrestanter 30. april kl. 16.45 til Kastellet og blev afleveret $\mathrm{i}$ »Kopenhagen-ZitadelleWache-Süd“. Lausten blev indsat i celle nr. 12, efter at man havde frataget ham livrem og barbergrej. ${ }^{50}$

Sent om eftermiddagen den 1. maj blev Lausten afhørt af krigsretten i Kastellet under forsæde af Oberkriegsgerichtsrat Jänz. Den tidligere Sønderborgadvokat $\mathrm{H}$. Johannsen virkede som udspørger. Ifølge udskriften af 2. maj blev Lausten præsenteret for »svært belastende bevismateriale«. Han skulle have spioneret mod Tyskland. Jänz gentog, at det var den i Flensborg fængslede Jens Dons, som havde fremført anklagerne. Lausten nægtede sig skyldig, hvorefter han blev ført tilbage til sin celle. Inden havde Jänz dog meddelt ham, at han ville blive konfronteret med Dons, der under afhøringerne i Flensborg havde oplyst, at han i 1933 eller 1934 af Smith fik til opgave at hverve en agent på vestkysten. Lausten og Dons kendte hinanden fra flere besøg på redaktionen $\mathrm{i}$ Tønder. ${ }^{51}$

I et senere forhør ændrede Dons dog forklaring. Han oplyste nu, at Smith tilsyneladende kendte Lausten, idet det var Smith, som havde bedt Dons om at opsøge Lausten for at høre, om han var interesseret $\mathbf{i}$ at skaffe nyhedsstof til amerikanske blade. Hvis han var interesseret, skulle Dons og Lausten køre til Esbjerg for at møde Smith. ${ }^{52}$

Lausten havde ifølge Dons indvilget $\mathrm{i}$ at tage med til Esbjerg, og 


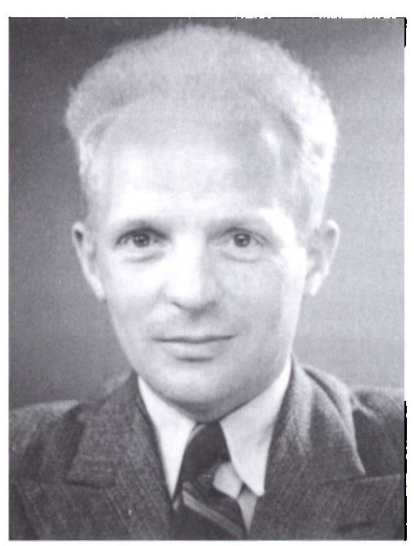

Viggo Lausten var medlem af det danske mindretal $i$ Sydslesvig, altså tysk statsborger. Han havde varet redaktor af Vestslesvigs Tidende siden begyndelsen af 1930'erne. Viggo Lausten blev arresteret den 20. april 1940, sigtet for spionage for England. Ti dage senere blev han overfort til Kastellet $i \mathrm{Ko}$ benhawn. Her døde han den 2. maj om morgenenofficielt havde han begaet selvmord. Foto: Arkivet ved Dansk Centralbibliotek for Sydslesvig.

de mødte Smith på Hotel Spangsbjerg. Dons oplyste under afhøringerne, at Lausten og Smith havde talt sammen i tre timer. Han havde ikke overhørt samtalen.

Da denne sag var den første krigsretssag, som blev gennemført i Danmark under 2. Verdenskrig, var Kastellet under indretning som arrest og krigsret, da de arresterede ankom 30. april. Arrestforvarer Karl Graf, 27 år, oplyste i forbindelse med det senere ligsyn af Peter Dons, at han var tiltrådt som arrestforvarer 1. maj kl. 14, hvor afhøringen af de indsatte var i fuld gang.

Der foreligger intet om Laustens situation, fra han sent på eftermiddagen eller først på aftenen den 1. maj efter endt afhøring blev ført tilbage til sin celle, og indtil den 2. maj om morgenen. Ved 8-tiden den 2. maj skulle Lausten have banket på sin celledør. Selv om der var en natpotte $\mathrm{i}$ cellen, er det nærliggende, at han ønskede at komme på toilettet. ${ }^{53}$ Fængselsbetjent Jakob Weitbrecht hørte Laustens banken, kiggede gennem glashullet i døren og så, at Lausten stod tæt ved døren. Lausten bad om at komme ud, og Weitbrecht svarede "Einen Moment «. Weitbrecht henvendte sig til arrestforvarer Karl Graf, der lige var tiltrådt sin vagt og nu var i gang med forberedelsen af fangernes morgenmad.

Da Graf, ifølge eget vidneudsagn, kun måtte lukke én fange ud ad gangen, og der tilsyneladende var én ude, fortsatte han, uanfægtet af Laustens anmodning, med at tilberede morgenmaden, og først efter 20-30 minutter, da klokken var mellem 8.20 og 8.30, låste han sig ind i celle nr. 12. Her fandt han Lausten livløs, liggende på maven på 
gulvet i en blodpøl, hængende i et slips, der var fæstnet til sengestolpen. Der var meget blod i sengen og på gulvet. På sengetæppet lå et halvt barberblad.

Graf oplyste, at Lausten var iklædt underbukser, natskjorte og pullover. Natpotten var fyldt. Graf konstaterede, at der intet livstegn var hos Lausten. Han låste sig ud af cellen og tilkaldte en læge. Den tilkaldte læge var den 28-årige Unterartz Kurt Ehemann.

Dr. Ehemann oplyste, at han blev tilkaldt pr. telefon kl. 8.30. Da han ankom til cellen, konstaterede han straks, at fangen var død. Lausten havde om halsen bundet et slips, som i den anden ende var fæstnet til sengestolpen. Lausten lå på maven med hovedet tæt ved sengestolpen. Dr. Ehemann skar slipset over, vendte afdøde om på ryggen og konstaterede, at der var et ca. $3,5 \mathrm{~cm}$ langt snitsår på begge håndled. Liget var endnu lidt varmt, men døden var indtrådt og blodudstrømningen stoppet. Samtidig med at dr. Ehemann blev tilkaldt, blev krigsrettens chef, Jänz, underrettet om dødsfaldet. Jänz tog straks kontakt til de danske myndigheder med henblik på en fælles besigtigelse og efterfølgende ligsyn.

Politikommissær Søren Glud indfandt sig efter ordre fra Jänz kl. 10.30 sammen med kriminalbetjent Hugo Andersen. ${ }^{54}$ Jänz havde udtrykt ønske om, at det danske kriminalpoliti deltog i den undersøgelse, som selvmordet gav anledning til. Jänz lagde fra starten stor vægt på, at afdøde var tysk statsborger.

Følgende personer var til stede $\mathrm{kl} .10 .30$ ved besigtigelsen i celle nr. 12: Oberkriegsgerichtsrat Jänz som dommer, Heeresjustitsinspektor Puttins som dokumentationstjenestemand, Dr. H. Johannsen som tolk, politikommissær Søren Glud, kriminalbetjent Hugo Andersen, overbetjent Egebjerg, som fotograf, Unterartz Dr. Kurt Ehemann, Assistentsartz Dr. Georg Hesterberg, Arresthausaufseher Karl Graf og Schütze Jakob Weitbrecht.

Dr. Hesterberg fra Höheres Kommando XXXI oplyste, at han først deltog i besigtigelsen fra $\mathrm{kl}$. 10.30, men han var alligevel overbevist om, at dødsfaldet skyldtes selvmord forårsaget af kvælning og blodtabet fra overskårede pulsårer. Han var overbevist om, at hængning var hovedårsagen til døden. Lausten havde kastet sig ud af sengen og med sin vægt forårsaget en strangulation. Herudover var blodtabet en medvirkende dødsårsag.

Ifølge rapporten fra Höheres Kommando XXXI erklærede repræsentanterne for det danske politi sig enige $i$, at der var tale om selv- 
mord. De danske repræsentanter afstod fra at tilkalde dansk læge, selv om de ifølge rapporten fik det tilbudt, og de danske repræsentanter mente ikke, at obduktion var nødvendig. Helt enige var de dog ikke, for politikommissær Søren Glud skrev samme dag i sin rapport, at "et af undertegnede fremsat ønske om obduktion blev efter omstændighederne frafaldet, hvorimod der var enighed om at afholde et medico-legalt ligsyn. «55

Den fælles besigtigelse blev afsluttet med, at der efter tysk ønske blev indgået følgende aftale: For det første skulle der afholdes medico-legalt ligsyn hos de danske myndigheder, men ingen obduktion. For det andet fik de danske myndigheder udleveret liget af Lausten, og de skulle underrette familien gennem politimester Agersted i Aabenraa. For det tredje: Såfremt der skulle udsendes en pressemeddelelse fra Höheres Kommando XXXI, det tyske gesandtskab eller det danske udenrigsministerium, skulle repræsentanterne være enige om teksten.

Hvorfor accepterede politikommissær Søren Glud denne tekst, når han umiddelbart efter lavede en rapport, hvoraf det fremgik, at han mente, at en obduktion var nødvendig? Glud bad politikommissær Wolf fra Station $3 \mathrm{om}$ at afholde det aftalte ligsyn, og politimester Agersted i Aabenraa blev bedt om at underrette afdødes familie. Ligsynet fandt sted 3. maj kl. 9.50 på Retsmedicinsk Institut i København. Til stede var politikommissær Wolf fra Station $3 \mathrm{og}$ læge H. Brocks.

Af attesten, der skal give oplysninger om sikre og utvivlsomme dødstegn, fremgik: Lausten havde begået selvmord. Brocks gjorde opmærksom på, at der på halsen var smårifter og overfladiske hudafskrabninger, på begge håndled var der ca. $4 \mathrm{~cm}$ lange snitsår og pulsårerne var skåret over. Døden skyldtes strangulation i forbindelse med pulsåreoverskæring. I attestens punkt 11 noterer Brocks, at det ikke er nødvendigt at foretage yderligere undersøgelser evt. legal obduktion. ${ }^{56}$

Det virker besynderligt, at læge $\mathrm{H}$. Brocks uden nogen argumentation blot svarer Nej på spørgsmålet, om obduktion er nødvendig. Han kendte den tyske rapport fra besigtigelsen i Kastellet, og han kendte Gluds rapport. Men Jänz ønskede ikke obduktion af »tysk statsborger « Viggo Lausten, hvorfor det er nærliggende at konkludere, at de danske myndigheder (politi og læger) for at undgå konfrontationer frafaldt kravet, for, som Glud skrev, »et ønske om obduktion blev efter omstændighederne frafaldet $\ll$.

Men to dage senere skulle man opleve, at Jänz uden betænkeligheder accepterede, at der kunne foretages obduktion af Peter A. Dons, 
en obduktion som viste, at hjertestoppet skyldtes forgiftning. Noget, som kun blev konstateret, fordi obduktion blev gennemført.

Laustens pas nr. 236/36, udstedt af det tyske konsulat i Aabenraa, blev sammen med hans andre ejendele den 4 . maj udleveret til Hillebrandts Ligkistemagasin, Dannebrogsgade 4 i København, så de kunne sende effekterne til Tønder sammen med Laustens lig.

Udenrigsministeriets pressebureau udsendte 3. maj følgende pressemeddelelse, der ikke blev sendt til Flensborg Avis:

»Vedr. tysk statsborger Viggo Lausten, Tønder. Tysk statsborger Viggo Lausten, Tønder, er på grund af stærk mistanke om, at han havde gjort sig skyldig i spionage og landsforræderi mod Tyskland, blevet anholdt $i$ henhold til domsmæssig kendelse. Han blev den 1. maj forhørt under retslige former. Under indtryk af det tungtvejende bevismateriale, der forelå mod anklagede, begik han dagen efter forhøret selvmord i fængselscellen. Dødsårsagen blev fastslået under retslige former, efter at det danske politi var tilkaldt.«

Nederst på pressemeddelelsen var påfort en instruks om, at "for så vidt noget blad onsker at bringe en meddelelse om sagen, må det kun ske ved gengivelse af ovenstående«.

Meddelelsen blev bragt i Dybbøl-Posten og andre blade den 4. maj 1940. Denne lakoniske meddelelse giver anledning til en lang række spørgsmål: Hvorfor mente Udenrigsministeriet, at det var nødvendigt at gøre pressen opmærksom på, at alene denne tekst og intet andet om Lausten måtte omtales. Skyldtes det respekten for et tysk krav? Hvorfor stod der kun, at Lausten var tysk statsborger, men ikke at han var redaktør af Flensborg Avis' lokaludgave - Vestslesvigs Tidende i Tønder? Hvorfor stod der intet om, at godt nok var Lausten tysk statsborger, men at han tilhørte det danske mindretal i Sydslesvig og havde boet i Danmark siden 1933? Skyldtes det at Flensborg Avis var en tysk avis, redigeret af tyske statsborgere, at Udenrigsministeriet "glemte" at sende meddelelsen til Flensborg Avis? Hvorfor reagerede de tyske myndigheder så kontant, da Flensborg Avis, efter at have læst om dødsfaldet i Politiken, ved redaktør Ernst Christiansen den 6. maj skrev en nekrolog »Kaldet bort« over deres betroede medarbejder? Hvorfor blev Flensborg Avis' restoplag den 7. maj beslaglagt og avisen forbudt at udkomme i de første 14 dage af juni, når andre blade, bl.a. 
Dybbøl-Posten i Sønderborg, den 9. og 10. maj i stort opsatte artikler beskrev Laustens jordefærd?

Den 2. maj kl. 14.40 sendte statsadvokat Harald Petersen et telegram klassificeret fortroligt til politimester Agersted i Aabenraa: »Arrestanten Viggo Peter Johannes Lausten (Flensborg 31/7-04) boende i Tønder, har dags dato morgen aflivet sig ved hængning i sin celle $\mathrm{i}$ Kastellet i København. Afdødes pårørende bedes underrettet snarest. Evt. forholdsordre ang. liget udbedes.«

Samme aften kl. 19.15 svarede politimester Agersted: "Hustruen underrettet gennem politimesteren i Tønder personligt. Hustruen ønsker liget sendt til Tønder snarest."

Den 3. maj sendte politimesteren i Aabenraa et telegram til Københavns opdagelsespoliti: "Politimesteren i Tønder meddeler, at enken efter arrestanten Lausten, der har aflivet sig ved hængning i Kastellets arrest, har anmodet om, at opdagelsespolitiet sætter sig i forbindelse med Forsikringsselskabet Hafnia police nr. 749802 med henblik på udfærdigelse af særlig dødsattest. Sct. Georgs Gildet har tilbudt at medvirke til overførslen gennem medlemmer i København.«

Den 4. maj kl. 12.12 svarede statsadvokat Harald Petersen politimesteren i Aabenraa: "Liget+effekter overføres efter adressen Politimesteren i Tønder i dag kl. 14. Ligsynsattest og skifteattest er pr. post tilsendt politimesteren $\mathrm{i}$ Tønder. Alle hidtidige omkostninger indtil ankomsten til Tønder er betalt af Københavns Opdagelsespoliti. Hafnia er underrettet om dødsfaldet. Har fået genpart af dødsattest. Har erklæret at formaliteterne er $\mathrm{i}$ orden og vil sende enken pengene. sign. Harald Petersen, statsadvokat - sign. Odmar, kriminalass.//Meissner..$^{57}$

Det interessante ved disse telegrammer er den høje grad af omsorg, som de danske myndigheder udviste i denne sag, når de formelt mente, at der var tale om et selvmord, begået af en tysk statsborger efter af en tysk krigsret at have fået forelagt meget belastende beviser om spionage.

Københavns Opdagelsespoliti betalte alle omkostninger. De sørgede for en ekstrem hurtig sagsbehandling hos forsikringsselskabet Hafnia, som på under ét døgn accepterede, at alle formalia var opfyldt, og at de snarest ville udbetale livsforsikringen til Karoline Lausten.

Og ikke mindst interessant er det, at telegrammet af 4. maj kl. 12.12, også var underskrevet af det tyske gesandtskabs presseattaché, Dr. Gustav Meissner, som i forbindelse med den forestående lukning af 
Flensborg Avis den 8. maj udtalte, »at man havde klare beviser for at Lausten havde spioneret på Helgoland “. ${ }^{58}$

Samme dag havde Meissner en samtale med forfatteren Ejnar Howalt om de problemer, der var for bibeholdelsen af et godt dansk-tysk samarbejde: "Han (Howalt) indser fuldstændigt dette og vil endnu en gang gøre et privat energisk forsøg på at advare. Desuden skal man allerede have planlagt $\mathrm{i}$ sagen Lausten at give et svar, så man under ingen omstændigheder får præsenteret betalte spioner som martyrer for nationen. ${ }^{59}$

Meissners bekymringer for, hvad Lausten-sagen kunne betyde for det dansk-tyske forhold, drøftede han også på et møde 9. maj med kreditforeningsdirektør Poul Rasmussen, hvor mødetemaet ellers var det danske landbrugs finansielle situation, herunder oprettelse af en toldunion. ${ }^{60}$ Rasmussen blev refereret for at have sagt følgende: „Fædrelandet [de danske nazisters dagblad, forf.] vil efter anmodning nu bringe en særlig troskabstilkendegivelse over for kongen og påtænker desuden at blamere [den konservative avis] Nationaltidende og udtale, at folk som Lausten ingenlunde anses for at være martyrer.«

Meissner fremlagde aldrig sine "beviser « mod Lausten. Journalisten G.S. Tscherning foreslog $\mathrm{i}$ august 1945 justitsministeren at afhøre Meissner, der sad interneret $\mathrm{i}$ dansk fangenskab, for at høre om de »klare « beviser mod Lausten. Meissner kunne uden problemer have været afhørt om Laustens påståede spionvirksomhed, idet han 4. maj 1948 blev afhørt af en af Folketinget nedsat kommission. Men ingen af kommissionens medlemmer stillede sporgsmål om sagen, Lausten eller andre af de arresterede. ${ }^{61}$

Denne totale tavshed omkring den første tyske krigsretssag i Danmark under 2. Verdenskrig virker besynderlig, ikke alene med baggrund i Tschernings brev til justitsministeren, men i høj grad også på baggrund af Meissners dagbogsnotater fra sine møder 8. og 9. maj 1940, hvor han var meget opsat på at få fremstillet sagen på en sådan måde, at Lausten ikke blev martyr. Og hvordan kunne Lausten være $i$ besiddelse af et halvt barberblad og et slips, når han ved ankomsten havde afleveret sine personlige ejendele, herunder barbergrej?

\section{Kriminalassistent Peter Andersen Dons, Haderslev}

Kriminalassistent Peter A. Dons var hovedtiltalte Jens Dons' lillebror. Han var gift med Pauline. I ægteskabet var der ingen børn. Efter endt 
skolegang i Langetved var han blevet uddannet som mejerist, men før 1920 var han blevet politibetjent og havde fået ansættelse ved politiet i Ålestrup. Efter Genforeningen var Dons kommet til Haderslev. I 1921 var han avanceret til overbetjent og i slutningen af $1930^{\prime}$ erne udnævnt til kriminalassistent. Han var i 1940 leder af politiets fremmedafdeling i Haderslev.

I forbindelse med SIPO's overvågning af Jens Dons i oktober og november 1939 dukkede Peter A. Dons' navn også op, og i en rapport blev det bemærket, "at der ved undersøgelser af sagen er fremkommet oplysninger, der lader formode, at kriminalassistent Dons er impliceret.«

Peter Dons gennemførte i 1938-39 ifølge broderen en længere rejse til Tyskland. Efter rejsen skrev han en rejseberetning, som også indeholdt observationer af tyske troppebevægelser. Denne beretning medførte, at Peter Dons fik forhøjet sit månedlige honorar til 400 kr. Det var som nævnt kun Jens Dons, der oplyste, at også broderen spionerede for englænderne. Alfred Petersen oplyste under sin afhøring "at han aldrig, heller ikke fra Jens Dons, som han dagligt talte med i fængslet i Flensborg, havde fảet oplysninger om, at Peter Dons var impliceret. « ${ }^{62}$

Peter Dons blev arresteret den 26. april 1940 og fik efter eget ønske lov at blive $\mathrm{i}$ arresten i Haderslev. Måske var hans hjerteproblemer medvirkende hertil. Ved anholdelsen nægtede Peter Dons sig skyldig i noget som helst ulovligt. Sammen med de ti andre arresterede blev han den 30. april 1940 overført til Kastellet i København. Peter Dons blev først afhørt af krigsretten i Kastellet den 3. maj, og her fik han forelagt anklagerne om spionage til fordel for England. Det fremgår ingen steder, om man foreholdt ham broderens belastende udsagn, men da dette skete under afhøringen af Lausten den 1. maj, er Peter Dons sikkert også blevet konfronteret med disse beskyldninger. Peter Dons nægtede sig fortsat skyldig, og efter endt afhøring blev han ført tilbage til cellen. Næste morgen den 4 . maj kl. 7.45 blev Peter Dons fundet død i sin celle.

Arrestforvarer Karl Graf tilkaldte straks den tyske læge dr. Oeding, der konstaterede, at døden var indtrådt. Oeding oplyste, at der ikke var tegn på ydre vold, og han mente ikke, at der var tale om selvmord. For at fjerne enhver tvivl anbefalede han, at der blev foretaget obduktion. Krigsretten modtog besked om dødsfaldet samme dag kl. 9.20 . 


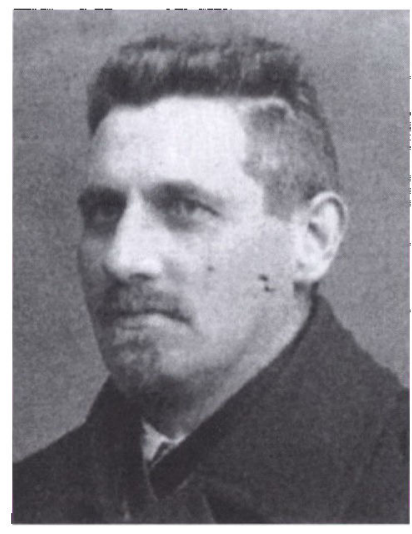

Kriminalassistent Peter Andersen Dons var lillebror til hovedtiltalte Jens Dons. Han blev arresteret den 26. april 1940, sigtet for spionage. Den 30. april 1940 blev han overfort til Kastellet $i$ København. Han blev fundet død $i$ sin celle den 4. maj 1940. Den efterfolgende obduktion viste, at Dons havde indtaget en overdosis af sin egen hjertemedicin. Foto: Odd Fellow-logen Hiort Lorenzen, Haderslev.

Der blev gennemført ligsyn i cellen under ledelse af Kriegsgerichtsrat Dr. Breuner. Efter opfordring fra Jänz deltog fra dansk side politikommissær Søren Glud og kriminalassistent Kay Andersen. Inspektør dr.med. W. Munck medvirkede som dansk læge. Overbetjent Egebjerg tog to fotos af afdøde. I forbindelse med afhøringen af personalet $\mathrm{i}$ Kastellet oplyste arrestforvarer Karl Graf, at Dons sidst var set i live den 3. maj kl. 21. Man havde undersøgt, om der i cellen fandtes genstande, der kunne benyttes til selvmord. Graf forklarede, at Dons lå på briksen. De havde bedt ham rejse sig, og da han forsøgte, skulle han have stønnet »Oh, mein Herz.«

Den 4. maj foretog dr. Munck et såkaldt medico-legalt ligsyn, og af attesten fremgår, "at det formentlig er en naturlig død i forbindelse med afdødes hjertesygdom. Der er ingen tegn på vold mod afdøde. Ingen objektive holdepunkter for forgiftning, men det sidste bør undersøges nærmere."

Peter Dons' hjertesygdom var bekræftet af læge Lauritzen i Haderslev, der havde udtalt, at "Peter A. Dons har gennem flere år lidt af en til tider ret generende muskelreumation«. Samme læge havde kort før anholdelsen sygemeldt Dons i fire uger på grund af hjerteproblemer.

Efter ligsynet blev det aftalt med Oberkriegsgerichtsrat Jänz, at der skulle foretages obduktion af Dons. Obduktionen blev foretaget den 5. maj kl. 9 på Københavns Universitetets Retsmedicinske Institut. Obduktionen, der blev foretaget af lægerne Sand og Munck, begyndte 
med det udgangspunkt, »at de stedfundne forandringer i hjertet indebærer hjertesvækkelse, og let kan forklare den pludselige død«.

Men så kom overraskelsen: De efterfølgende udtagne prøver af organerne viste, at der var tale om en forgiftning på grund af barbitursyreforbindelser. Derfor ændrede lægerne deres teori, som nu gik ud på, at "at døden skyldtes forgiftning med barbitursyreforbindelse kombineret med den i forvejen bestående hjertekarlidelse. « ${ }^{63}$

De gjorde endvidere opmærksom på, at der var svundet meget $i$ den hjertemedicin, som læge Lauritzen den 29. april havde ordineret. Af $500 \mathrm{ml}$ var der kun $200 \mathrm{ml}$ tilbage. 11 dage efter obduktionen den 16. maj 1940 skrev statsadvokat Harald Petersen til Justitsministeriet, at »ligsynsforretningen vedr. Dons er endnu ikke afsluttet, men genpart vil senere blive fremsendt."

Men obduktionen var for længst afsluttet. Hvorfor ville Harald Petersen ikke oplyse dødsårsagen over for Justitsministeriet?

I en dødsannonce indrykket den 6. maj 1940 i Dybbøl-Posten stod der blot følgende:

"Min kære mand kriminalassistent Peter Dons er afgået ved døden den 4. maj 1940. Haderslev den 6. maj 1940, Pauline Dons.“

Annoncen indeholdt ingen oplysning om begravelse, hvilket kan skyldes, at der gik lang tid, før liget blev frigivet efter obduktionen. Først den 28. maj sendte Harald Petersen genparter af ligsyn og obduktionsforretningen til Jänz, og samme dag under henvisning til skrivelsen af 16. maj blev de samme oplysninger sendt til Justitsministeriet. $^{64}$

\section{Hvad kan man udlede af denne sag?}

I regeringen og Folketinget var man i slutningen af 1930'erne med baggrund i de dramatiske hændelser i Europa meget nervøse for, hvad der kunne ske i Danmark, og man ville ikke medvirke til noget, som kunne provokere den aggressive nabo mod syd. Derfor strammede Folketinget og Landstinget i 1939 den borgerlige straffelov, så enhver form for medvirken til fordel for en fremmed stats efterretningsvæsen kunne straffes med indtil seks års fængsel mod tidligere indtil to år.

En konsekvens af loven var etableringen af det danske sikkerhedspoliti (SIPO) den 1. maj 1939. Det er dokumenteret, at der efter 1. maj 
1939 var tætte forbindelser mellem den danske rigspolitichef, chefen for SIPO og tyske Gestapo.

Engelske Secret Service hvervede fra sit kontor i British Passport Office, Bornholmsgade 3 i Kobenhavn, danskere til at foretage observationer og mod betaling rapportere til Secret Service. Sønderjylland - som grænseområde mod Tyskland - havde englændernes særlige interesse.

Det er bevist, at hovedpersonerne Jens Dons og Alfred Petersen forsynede Secret Service med oplysninger. Man kan diskutere, om nogle af disse oplysninger var andet, end hvad enhver borger, som havde besøgt området, kunne tegne på et stykke papir eller læse i aviser, men der er næppe tvivl om, at der i henhold til førnævnte lov var tale om hjælp til en fremmed stats efterretningsvæsen, uanset at observationerne oftest foregik på agenternes rejser i Nordtyskland.

Om det hos Dons og Petersen var idealisme og et sandt ønske om at bekæmpe nazismen, er meget tvivlsomt. Det er min opfattelse ud fra vidneudsagn, at det var den kontante afregning, for Petersens vedkommende kombineret med eventyrlyst, der drev værket. Dons og Petersen blev hver idømt fem års fængsel for spionage. I forhold til skadevirkningerne en streng straf, der mere bar præg af dansk lydighed over for besættelsesmagten end ønsket om retfærdighed, man må dog tage hensyn til at såfremt de var blevet dømt i Tyskland så kunne dommen have medført dødsstraf, så set i det lys var de sikkert tilfredse med at blive dømt efter dansk lovgivning.

Af de 11 sønderjyder, som blev fængslet og afhørt i Kastellet, viste det sig hurtigt, at materialet mod de otte var så tyndt, at de i løbet af en måned alle var på fri fod. De tre sidste var Hans Peter Lythje, Peter Andersen Dons og Viggo Lausten. Lythje fik samme straf - fem års fængsel - som Jens Dons og Alfred Petersen, og tilstod, at han mod betaling havde spioneret til fordel for englænderne. Peter Andersen Dons døde den 4. maj $1940 \mathrm{i}$ celle nr. 7 af en overdosis af sin egen medicin. Viggo Lausten døde den 2. maj 1940 i celle nr. 12 under mystiske omstændigheder.

\section{Eftertidens berøringsangst}

Viggo Lausten blev afhørt af krigsretten den 1. maj fra midt på eftermiddagen og til først på aftenen. Uanset at såvel Oberkriegsgerichtsrat Jänz som presseattaché dr. Meissner efterfølgende påstod, at Viggo 
Lausten blev konfronteret med de belastende beskyldninger, som Dons havde fremsat under afhøringer i Flensborg, må det anses for givet, at Lausten har nægtet sig skyldig i spionage mod Tyskland.

Det er sandsynligt, at Lausten og Dons mødtes med den engelske Secret Service-agent på Hotel Spangsbjerg i Esbjerg. Det er også muligt, at Lausten lavede nogle tegninger til Dons over havneanlæg på Sild og Helgoland. Men han har sikkert nægtet dette under afhøringerne. Påstanden om såvel mødet $\mathrm{i}$ Esbjerg som tegningerne blev alene fremsat af Dons. Ingen af de andre sigtede belastede under afhøringerne Lausten.

For at sætte trumf på meddelte Jänz inden retsmødet blev afsluttet, at Lausten ville blive konfronteret med Jens Dons, uagtet at Dons sad fængslet i Flensborg. Det, som måske kunne påvirke Lausten mest, var, at han som tysk statsborger risikerede dødsstraf for spionage mod sin hjemstat.

Dette var situationen, da Lausten om aftenen den 1. maj blev ført tilbage til celle nr. 12. Man kan kun gisne om, hvad der skete om natten. Modtog Lausten besøg i cellen? Var han udsat for fysisk eller psykisk tortur? Spillede politikommissær Hans Hermannsen en rolle denne nat? Det er spørgsmål, som for altid forbliver ubesvarede, medmindre der f. eks. i Sydslesvig dukker ny viden op.

Det kan ikke udelukkes, at Lausten var betalt spion for det engelske efterretningsvæsen, men det er ikke på nogen måde dokumenteret. Eneste endnu ikke afprøvede mulighed er nok Secret Service's endnu lukkede arkiv. Et møde i Esbjerg var næppe strafbart efter loven, før der blev indgået en aftale, og skulle Lausten virkelig have forsynet Dons med nogle frihåndstegninger over militære anlæg, så havde Gestapo nok gjort mere ud af disse beviser i forbindelse med afhøringerne af Dons. Selv om Lausten i sine unge år var spejder med mod på eventyr, har han nok været meget opmærksom på det farlige $i$ at være engelsk spion og tysk statsborger. Jeg hælder til teorien, at det er muligt, at Lausten har lavet nogle frihåndstegninger, der viste, hvad han kunne huske af forholdene på Sild og Helgoland. Han har måske også givet dem til Dons. Men der er langt til, at man derfor kan kalde ham spion, og der er ingen beviser for, at han modtog betaling.

Lausten døde i sin celle mellem kl. 8 og 8.30 den 2 . maj, efter at han iflg. fangevogterne skulle have bedt om at komme på toilettet. Hvorfor skulle Lausten bede om at komme ud, hvis han havde besluttet at begå selvmord? 
Ved ankomsten til Kastellet den 30. april måtte Lausten aflevere personlige ejendele. Hvorfor var Lausten denne morgen så i besiddelse af et halvt barberblad og slips? Hvorfor nægtede de tyske myndigheder, at Laustens lig blev obduceret? Hvorfor bekræftede det danske politi, at det var indforstået med, »at der på grund af omstændighederne « ikke blev foretaget obduktion, når de reelt mente, at det var nødvendigt? Hvorfor skulle det i en pressemeddelelse slås fast, at Lausten var tysk statsborger, men ikke også oplyses, at han var dansksindet sydslesviger, der i syv år havde arbejdet i Danmark? Hvorfor måtte pressen kun bringe pressemeddelelsen med det ordvalg, som de danske og tyske myndigheder havde besluttet? Hvorfor fik alene pressen i Danmark meddelelsen, når man vidste, at Flensborg Avis naturligvis havde stor interesse i en sag, hvor en medarbejder var afgået ved døden? Hvorfor var der ikke sanktioner mod de danske aviser, som skrev mere end indholdet af pressemeddelelsen? Hvorfor blev Flensborg Avis lukket i 14 dage med baggrund i en udramatisk omtale af dødsfaldet? Hvorfor fremlagde Meissner aldrig de beviser, som han påstod at have, og som skulle sikre, at Lausten ikke blev martyr? Hvorfor blev Meissner ikke konfronteret med sine egne påstande, da han blev afhørt af Folketingets kommission? Hvorfor lagde man så stort pres på Hafnia for at få klargjort Laustens livsforsikring til udbetaling med en hurtighed, der næppe er set før eller siden?

Jeg kan ikke afvise, at Lausten begik selvmord. Men uanset udsigten til konfrontationen med Jens Dons og en særlig hård straf som tysk statsborger, er der meget, der taler imod, at han skulle gå i panik og begå selvmord. Der er intet, der bestyrker mig i, at en stærk person som Lausten skulle vælge denne udvej. ${ }^{65}$

Der kan være sket noget dramatisk i celle nr. 12 om natten eller om morgenen den 2. maj 1940. Jeg tror ikke, fangevogter Weitbrecht og arrestforvarer Graf så Lausten i live i cellen mellem kl. 8 og 8.30. Jeg tror heller ikke på, at Lausten kunne have smuglet et halvt barberblad og et slips ind i cellen. Derfor anser jeg Viggo Lausten for at være den første person, som efter den tyske besættelse blev likvideret.

Det er dybt beklageligt, at der efter krigen ikke var interesse for tilbundsgående at undersøge sagen. Det havde været rimeligt, at man havde afhørt de danske ministre, som på ministermøder i april fulgte sagen, men som efter fangernes overflytning til Kastellet reelt lukkede øjnene for det tyske brud på indgåede aftaler. Politikommissær Søren 
Glud kunne have fortalt, hvorfor han mente, at obduktion var nødvendig. Meissner og Hermannsen, som begge var fængslet i Danmark flere år efter krigen, ville have været vigtige vidner. Selv om Folketingets kommission i 1948 afhørte Meissner, kom intet frem om hverken krigsretssagen, hans påståede beviser mod Lausten eller de to dødsfald.

Et sidste forsøg blev gjort i 1971, hvor der blev stillet spørgsmål til daværende justitsminister Knud Thestrup. Justitsministeren besvarede de stillede spørgsmål med at oplyse, hvad der lå i sagen. Men han tog ikke initiativ til at gennemføre undersøgelser, som på daværende tidspunkt kunne have belyst sagen, fordi folk, som var involverede, stadig levede. Det gør de ikke i dag. Hvorfor oplyste Thestrup ikke, at Peter Dons' død skyldtes en overdosis af medicin, som forårsagede hjertestoppet?

SIPO's overvågning af Dons og Petersen i 1939 og 1940 blev sat i gang efter en henvendelse fra folketingsmedlem Jørgen Gram, Gabøl. Det er ærgerligt, at man ikke efter krigen spurgte Gram, der var medlem af den kommission, som undersøgte de danske myndigheders gøren og laden under besættelsen, hvorfor han henvendte sig til SIPO med oplysninger om, at en sønderjyde sad inde med oplysninger om to landsmænds spionage.

Kommissionen undgik som nævnt at beskæftige sig med sagen, selvom Jørgen Gram næppe har kunnet undlade at tænke på de konsekvenser, hans henvendelse til SIPO fik. Han burde om nogen have været interesseret $\mathrm{i}$ at få at vide, hvordan tysk militær mindre end 36 timer efter besættelsen kunne »kidnappe« Dons og Petersen og føre dem til Flensborg. I hele perioden fra SIPO's oprettelse i foråret $1939 \mathrm{og}$ frem til april 1940 var der tætte relationer mellem rigspolitichef $\mathrm{E}$. Thune Jacobsen og SIPO-chef Emil Strøbech til Gestapo i Berlin og Kiel. Det er ikke umuligt, at personer med tilknytning til SIPO eller med kendskab til overvågningerne gav deres viden til tyskerne. I forbindelse med kommissionens afhøringer af Thune Jacobsen og Strøbech er de tætte relationer bekræftet, selv om Thune Jacobsen forsøgte at undvige.

Selv om Dons og Petersen blev ført til Flensborg den 12. april, gjorde det danske udenrigsministerium først opmærksom på deres forsvinden den 20. (Petersen) og den 24. april (Dons), da Udenrigsministeriets direktør Mohr i to breve til Renthe-Fink protesterede og bad om, at de arresterede straks blev ført tilbage til Danmark. ${ }^{66}$ At Udenrigsministeriet først den 24 . blev opmærksom på Dons' forsvinden, 
skyldtes dog en intern kommunikationsbrist, idet statsadvokat Harald Petersen den 19. april i forbindelse med tyskernes krav om anholdelser havde fået oplyst, at Dons var fængslet i Flensborg.

Regeringen fulgte opmærksomt bestræbelserne på at få de fængslede udleveret indtil den 30. april 1940. Men nøjagtig samtidig med, at de 11 fængslede i Aabenraa og Haderslev blev ført til Kastellet, forsvandt regeringens interesse for sagen.

Den 5. juli 1947 afgav minister uden portefølje P. Federspiel fra Venstre en redegørelse til kommissionen af 19. december $1945 .{ }^{67} \mathrm{Her}$ fremgår det, at Dons og Petersen kort efter besættelsen sammen med fire andre var blevet ført til Flensborg, og at SIPO havde haft brødrene Dons og Petersen under observation før besættelsen, uden at man skred til anholdelse. Dons og Petersen var fængslet i Flensborg, indtil de efter underhåndsforhandlinger mellem den tyske besættelsesmagt og statsadvokaten i august 1940 blev udleveret til retsforfølgning i København. Sandheden er nok nærmere, at tyskerne ikke længere havde interesse $\mathbf{i}$ dem.

Det er interessant, at der i samme redegørelse helt klart tages stilling til, hvordan Lausten døde: "såvel han (Peter Dons) som redaktør Lausten fra Tønder, der ligeledes var anholdt efter tysk krav sigtet for spionage, døde i Kastellet, i hvert fald for Laustens vedkommende ved selvmord.«

Til trods for, at dødsattesterne var i Justitsministeriets varetægt, blev det ikke nævnt, at politikommissær Søren Glud havde ønsket en obduktion, men frafaldt kravet »efter omstændighederne«. I Peter Dons' tilfælde blev der gennemført en obduktion, som viste, at Dons var død af et hjertestop forårsaget af en overdosis af hans egen medicin.

Skyldtes den manglende interesse for at opklare sagen, at den kunne afsløre ubehagelige, tætte forbindelser mellem det danske sikkerhedspoliti (SIPO) og Gestapo allerede fra SIPOs etablering i foråret 1939, at en dansk lækage i dagene 9.-11. april var årsag til, at Jens Dons og Alfred Petersen blev »kidnappet « den 12. april om morgen og ført til Flensborg, og at den danske regering ikke ønskede at få stillet spørgsmålet: Hvorfor faldt interessen for sagen stort set samtidig med de to dødsfald i Kastellet?

Spørgsmålet om, hvordan Viggo Lausten døde, er indgående blevet behandlet af H.E. Sørensen, René Rasmussen og Frants Thygesen, der alle hælder til teorien, at Lausten begik selvmord. Måske på grund af 
de såkaldte tunge beviser, måske fordi han frygtede for sin skæbne, da han var tysk statsborger, eller måske fordi han gik i panik.

Det bliver aldrig opklaret, om Lausten begik selvmord, eller om han, som det er min teori, blev myrdet. Han bankede ikke på sin celledør kl. 8 om morgenen, fordi han på det tidspunkt var død. Jeg stiller spørgsmålet: Er det på 20 minutter muligt at binde sig til sengestolpen, skære begge pulsårer over, kaste sig ud af sengen, blive kvalt i et slips, og så dø? En obduktion kunne have opklaret dette, men det ville tyskerne ikke. Risikoen for at finde den reelle dødsårsag var for stor.

Et andet spørgsmål: Hvordan kom Lausten i besiddelse af et barberblad og et slips, når han ved ankomsten til Kastellet havde afleveret sit barbergrej? Vagterne kan naturligvis have udleveret det og glemt at få det tilbage. Men der var kun et halvt barberblad. Hvor var den anden halvdel? Frantz Thygesen refererer i en artikel fra 1985 tidligere politimester Erik Bøving, Tønder, der mente at have set et foto af Lausten hængende ved sengestolpen. Et sådant foto findes ikke. I Justitsministeriets arkiv findes et billede af Lausten liggende død på gulvet. Han ligger på ryggen og uden et slips bundet til sengestolpen. ${ }^{68}$

Selvom min teori ikke er bedre end andres, så tror jeg, at Lausten tidligt om morgenen fik tysk hjælp til sit »selvmord«. Eller sagt direkte: Lausten blev myrdet.

Var Lausten engelsk spion? Det mener jeg ikke. Han mødtes med Smith i Esbjerg, hvilket næppe kan betegnes som strafbart. Det kan heller ikke betragtes som spionage, såfremt Lausten skulle have lavet et par frihåndstegninger efter sin hukommelse af militære anlæg på Sild eller Helgoland. Alene Jens Dons beskyldte Lausten for at være spion og blive betalt herfor. På baggrund heraf kunne Lausten næppe dømmes for spionage efter straffelovens $\S 105$. Alene en åbning af arkiverne hos Secret Service vil måske kunne give et andet svar.

For så vidt angår Peter Dons, er det bevist, at han døde af en overdosis af sin egen medicin. Han kan naturligvis have taget for meget medicin frivilligt, men også her er det min opfattelse: Han blev myrdet.

\section{Epilog}

Dette er historien om fjeren, der blev til syv høns. En henvendelse til SIPO om formodet spionvirksomhed mod Tyskland medførte overvågning af de mistænkte. Mere skete der ikke. Men oplysninger kom 
i den tyske besættelsesmagts hænder før eller ultrakort tid efter besættelsen. Med beskyldningen om spionage skete der anholdelser, fængslinger, og fremstilling for den tyske krigsret i Kastellet. De fleste blev hurtigt sat på fri fod. Der var ingen hold i anklagerne. Tre fik strenge straffe tæt på lovens maksimum for en aktivitet, som de fleste i dag ville betragte som fornuftig handling over for den tyske aggressor, men som fra 1939 kunne straffes med lange fængselsstraffe. Man kan dog ikke undlade en bemærkning om, at den tyske besættelsesmagt næppe havde set med milde øjne på korte straffe eller frifindelse. For Lausten og Peter Dons fik sagen de værst tænkelige følger døden.

For mig vil det altid stå som en gåde: Hvorfor ville de danske myndigheder ikke have denne sag opklaret?

\section{LITTERATUR OG KILDER}

\section{Upubliceret materiale}

\section{RIGSARKIVET (RA)}

Forfatteren har fået særlig adgang til klausuleret materiale i Rigsarkivet. Materialet befinder sig i to uordnede kasser med titlen: "Statsadvokaten for særlige Anliggender, UK-sag nr. 4 vedr. Viggo Lausten.«

\section{LANDSARKIVET (LAA)}

P-106-22 Ernst Christiansens privatarkiv

\section{Publiceret materiale}

Carl Johan Bech. Da de kom. Folkung Forlaget 1945.

Jesper Bolund Nielsen: Dansk spejder- arbejde i Flensborg 1919-1939 - en kastebold i grænsekampen. Sønderjyske Årbøger 2005, s. 95-132.

René Rasmussen: Front og Bro. Flensborg Avis i spil mellem Danmark og Tyskland 1930-1945. Flensborg 2005.

H.E. Sørensen: Døden i Kastellet 1971.

Frants Thygesen: Viggo Laustens død i fængsel for 50 år siden (artikelserie i Flensborg Avis 04.12.1985ff.)

Folketingstidende 1938-1939

Beretning til Folketinget afgivet af den 8. januar 1948 nedsatte kommission VII a. Bind 1-3.

Beretning til Folketinget fra den af 25. oktober 1950 nedsatte kommission XIIIa bind 1 og 4.

Dybbol-Posten

Jydske Tidende

Flensborg Avis

\section{NOTER}

1. Folketingstidende for $1938 / 39$ den 1. marts, side 4666 .

2. Bilag til Beretning til Folketinget afgivet af den 8 . januar 1948 nedsatte kommission VII a. Bind 1 s. 646.

3. H.E. Sørensen: Doden i Kastellet

1971, s.45f. og Beretning 1948, VII a Bind 1 s. $679 \mathrm{f}$.

4. Sørensen 1971, s. $45 \mathrm{f}$.

5. Ibid. s. $64 \mathrm{ff}$.

6. Ibid. s. $107 \mathrm{f}$.

7. Beretning til Folketinget afgivet af 
den 8. januar 1948 nedsatte Kommission VII a. Bind 3 st. s. $27 \mathrm{f}$.

8. Rigsregistraturen er et under Rigspolitiet henhørende kartotek over kriminelle personer (»Forbryderkartoteket «).

9. Rapport fra SIPO den 11. oktober 1939. RA UK-sag nr. 4 vedr. Viggo Lausten.

10. Sandsynligvis et dæknavn for Major Bernhard Joseph O'Leary (f. 20/8-1890).

11. Rapport fra SIPO den 11. oktober 1939. RA UK-sag nr. 4 vedr. Viggo Lausten.

12. Rapport fra SIPO af 4/11 1939. RA UK-sag nr. 4 vedr. Viggo Lausten.

13. Rapport far SIPO af 16/11-1939. RA UK-sag nr. 4 vedr. Viggo Lausten.

14. Beretning 1948 VII Bind 3 a st. 99.

15. Beretning 1948 IV Bind 1 a. Bilag s. 46 og 61.

16. Beretning 1948 IV Bind 1 a. s. 556.

17. RA UK-sag nr. 4 vedr. Viggo Lausten.

18. Beretning 1948 IV Bind 1 a. s. $412 \mathrm{ff}$.

19. Beretning 1948 VII Bind 1 a. s. 79 ff.

20. Beretning 1948 IV Bind 1 a. s. 416.

21. Beretning $1948 \mathrm{VII}$ a. Bind $1 \mathrm{~s}$. $79 \mathrm{ff}$.

22. RA UK-sag nr. 4 vedr. Viggo Lausten.

23. Beretning 1948 VII a. Bind 1 s. $79 \mathrm{ff}$.

24. Beretning 1948 VII a. Bind 2 s. 924. På side 926 fremgår det, at Hermannsen med start den 8 . august 1947 blev afhørt af Kommissionsdomstolen. Hermannsen forklarede, at han, der var grænsepolitikommissær i Flensborg, kom til Kobenhavn den 20. april og blev ansat under Der Bevollmächtigte, hvor Kanstein var hans foresatte. Selvom det ikke har den store betydning, om Hermannsen kom til Kobenhavn den 20. eller den 29./ 30. april, er det min opfattelse, at 29. eller 30. april er den mest sandsynlige ankomstdato.

25. Indberetning af 16 . maj 1940 fra statsadvokat Harald Petersen. RA UK-sag nr. 4 vedr. Viggo Lausten.

26. Brev af 13. marts 1941. Den kst. statsadvokat meddeler, at der på grund af bevisets stilling ikke foretages mere. RA UK-sag nr. 4 vedr. Viggo Lausten.

27. Forhørsprotokol Grenzpolizei Komm. Flensburg III D 99/389, 15. Og 29. april samt 22. maj 1940. RA UK-sag nr. 4 vedr. Viggo Lausten.

28. Nekrolog den 26. april 1937 i Dybbel-Posten. Den 28. april 1937 i Jydske Tidende.

29. Afskrift af forhørsprotokol i Flensborg s. 13 og 62. RA UK-sag nr. 4 vedr. Viggo Lausten.

30. Afskrift af forhørsprotokol fra Flensborg den 15. april 1940 s. 14. RA UK-sag nr. 4 vedr. Viggo Lausten.

31. Afhøringerne af Jens Dons i Kobenhavn den 16. -24 . oktober 1940 og afskrift af forhørsprotokol fra Flensborg den 22 . maj 1940 s. $66 \mathrm{f}$. RA UK-sag nr. 4 vedr. Viggo Lausten.

32. RA UK-sag nr. 4 vedr. Viggo Lausten.

33. Flensborg Avis den 28. januar1971.

34. Håndskrevet kopi af brev fra Jens Dons til Kongen. RA UK-sag nr. 4 vedr. Viggo Lausten.

35. Brev af 13. december1940 til Statsadvokaten. RA UK-sag nr. 4 vedr. Viggo Lausten.

36. Indberetning den 17. oktober 1941 til Justitsministeriet fra Inspektøren ved Statsfængslet i Horsens. RA UK-sag nr. 4 vedr. Viggo Lausten.

37. Blyantsnotat på grønt sagsomslag RA UK-sag nr. 4 vedr. Viggo Lausten.

38. Oplysning fra Johan S. Nissen, Bevtoft.

39. Jydske Tidende 9. januar 1947.

40. Indberetning af 16 . maj 1940 fra statsadvokat Harald Petersen til Justitsministeriet. RA UK-sag nr. 4 vedr. Viggo Lausten.

41. Afskrift på tysk af forhørsprotokol Retten i Flensborg 15. april, 29. april og 22. maj1940. RA UK-sag nr. 4 vedr. Viggo Lausten.

42. Brev fra G. S. Tscherning til Justitsministeriet den 27. august 1945. RA UK-sag nr. 4 vedr. Viggo Lausten. 
43. Sørensen 1971, s. 33.

44. Ibid, s. 29.

45. Jesper Bolund Nielsen 2005, s. 95 132.

46. Srrensen 1971, s. 35.

47. Ibid., s. 35.

48. C. J. Bech: Da de kom. Folkung Forlaget 1945. Side XXX

49. Bech 1945, s. XXX og LAA P106-22 Karoline Lausten til Ernst Christiansen 22.4.1940.

50. Afskrift fra den 2. maj 1940 Gericht des Höheren Kommandos z.b.v. XXXI. RA UK-sag nr. 4 vedr. Viggo Lausten.

51. Afskrift af afhøringerne i Flensborg den 15. april 1940. RA UK-sag nr. 4 vedr. Viggo Lausten.

52. Forhør hos kriminalassistent Hugo Andersen den 16. oktober 1940. RA UK-sag nr. 4 vedr. Viggo Lausten.

53. Afskrift fra den 2. maj1940 Gericht des Höheren Kommandos z.b.v. XXXI. RA UK-sag nr. 4 vedr. Viggo Lausten.

54. Kjøbenhavns Opdagelsespoliti rapport af torsdag den 2. maj 1940. RA UK-sag nr. 4 vedr. Viggo Lausten.

55. Ibid.

56. Læge H. Brocks attest af 3. maj 1940 i forbindelse med ligsynet af Viggo Lausten. RA UK-sag nr. 4 vedr. Viggo Lausten.

57. Telegrammer. RA UK-sag nr. 4 vedr. Viggo Lausten.

58. Ibid.
59. Beretning 1950 XIII a. Bind 4 s. 62 .

60. Beretning 1950 XIII a. Bind 4 s. 61 .

61. Beretning 1950 XII a Bind 1 s. 41631.

62. Tillag til rapport om Jens Dons af 31. oktober 1939. RA UK-sag nr. 4 vedr. Viggo Lausten.

63. Barbitursyre er et farveløst krystallinsk stof. Barbitursyrepræparater elimineres langsomt fra organismen, hvilket kan forårsage en langsom kronisk forgiftning. Storre doser end de terapeutisk anvendte virker stærkt giftige og kan medføre døden (laboratorieforstander, civilingeniør Knud E. Nielsen i Nordisk Konversations Leksikon bind I s. 412 6.oplag 1967).

64. Statadv. Harald Petersens genparter af ligsyn og obduktion til Justitsministeriet. RA UK-sag nr. 4 vedr. Viggo Lausten.

65. Selvmordsteorien stottes af H. E. Sørensen i Døden i Kastellet 1971 og af René Rasmussen i Front og Bro. 2005.

66. Bilag til beretning til Folketinget fra kommissionen af 8 . januar 1948 bilag 30 a side 72 og bilag 33 side 77.

67. Bilag til beretning til Folketinget fra kommissionen af 8. januar 1948 side $181 \mathrm{ff}$.

68. Frants Thygesen: Viggo Laustens ded $\mathrm{i}$ fængsel for 45 år siden (artikelserie $i$ Flensborg Avis 4.12.1985ff). 